\title{
Coral-associated nitrogen fixation rates and diazotrophic diversity on a nutrient-replete equatorial reef
}

\author{
Molly A. Moynihan (iD ${ }^{1,2}{ }^{凶}$, Nathalie F. Goodkin (iD ${ }^{2,3,4}$, Kyle M. Morgan (iD) ${ }^{2}$, Phyllis Y. Y. Kho (iD) ${ }^{2}$, Adriana Lopes dos Santos (iD) ${ }^{2}$,
} Federico M. Lauro (iD) ${ }^{2,5}$, David M. Baker (iD ${ }^{6,7}$ and Patrick Martin (iD) ${ }^{2}$

(c) The Author(s) 2021

The role of diazotrophs in coral physiology and reef biogeochemistry remains poorly understood, in part because $\mathrm{N}_{2}$ fixation rates and diazotrophic community composition have only been jointly analyzed in the tissue of one tropical coral species. We performed field-based ${ }^{15} \mathrm{~N}_{2}$ tracer incubations during nutrient-replete conditions to measure diazotroph-derived nitrogen (DDN) assimilation into three species of scleractinian coral (Pocillopora acuta, Goniopora columna, Platygyra sinensis). Using multi-marker metabarcoding (16S rRNA, nifH, 18S rRNA), we analyzed DNA- and RNA-based communities in coral tissue and skeleton. Despite low $\mathrm{N}_{2}$ fixation rates, DDN assimilation supplied up to $6 \%$ of the holobiont's $\mathrm{N}$ demand. Active coral-associated diazotrophs were chiefly Cluster I (aerobes or facultative anaerobes), suggesting that oxygen may control coral-associated diazotrophy. Highest $\mathrm{N}_{2}$ fixation rates were observed in the endolithic community $\left(0.20 \mu \mathrm{g} \mathrm{N} \mathrm{cm}{ }^{-2}\right.$ per day). While the diazotrophic community was similar between the tissue and skeleton, RNA:DNA ratios indicate potential differences in relative diazotrophic activity between these compartments. In Pocillopora, DDN was found in endolithic, host, and symbiont compartments, while diazotrophic nifH sequences were only observed in the endolithic layer, suggesting a possible DDN exchange between the endolithic community and the overlying coral tissue. Our findings demonstrate that coral-associated diazotrophy is significant, even in nutrient-rich waters, and suggest that endolithic microbes are major contributors to coral nitrogen cycling on reefs.

The ISME Journal (2022) 16:233-246; https://doi.org/10.1038/s41396-021-01054-1

\section{INTRODUCTION}

Nitrogen $(\mathrm{N})$ is considered the major limiting nutrient on coral reefs, with dissolved inorganic nitrogen (DIN) concentrations typically $<1 \mu \mathrm{M}$ [1]. Corals nevertheless create highly productive and diverse ecosystems [2], which is largely attributed to efficient carbon and nitrogen recycling with their endosymbiotic algae (Symbiodiniaceae). Corals also harbor a diverse microbial community, comprised of Bacteria, Archaea, and single-celled Eukarya [3]. Although direct observations of these microorganisms are sparse, they can be major sources of nutrients for corals $[4,5]$. Among coral-associated microorganisms, dinitrogen $\left(\mathrm{N}_{2}\right)$ fixing Bacteria and Archaea, known as diazotrophs, are believed to play an important role in coral physiology and reef biogeochemistry [6]. Diazotrophs are a source of new nitrogen, and coral-associated diazotrophs can contribute up to $18 \%$ of gross benthic $\mathrm{N}_{2}$ fixation in shallow fore-reef environments [7]. Diazotrophs have been found in bulk analyses of the coral microbial community [8], and assimilation of diazotroph-derived nitrogen (DDN) has been documented within the coral mucus, host tissue, algal symbionts, and skeleton [8-11].

Despite several rate-based observations of $\mathrm{N}_{2}$ fixation in corals, the significance, variability, and fate of coral-associated $\mathrm{N}_{2}$ fixation remain poorly understood. Several studies observed that the majority of DDN was acquired by Symbiodiniaceae $[8,12-14]$ and could meet up to $11 \%$ of their $\mathrm{N}$ demand [15]. Yet, others found little to no transfer of fixed nitrogen to Symbiodiniaceae, but reported that DDN was lost to the water column $[9,16]$ (n.b. results from [16] may have been underestimated [17] by use of the bubble method [18]). In comparing species, one study found that autotrophic corals (Pocillopora verrucosa, Stylophora pistillata) rely more on DDN than heterotrophic corals (Fungiidae) [10]. Other studies have highlighted the role of heterotrophy in DDN assimilation [19], and significant rates of diazotroph ingestion and DDN assimilation have been observed in Stylophora pistillata $[14,20]$, particularly during bleaching [20]. However, environmental conditions have an uncertain role in coral-associated diazotrophy. While $\mathrm{N}_{2}$ fixation rates appear to increase with temperature [21, 22], DDN assimilation in coral has been observed to both increase $[19,20]$ and decrease [23] in bleached corals. During bleaching, DDN is hypothesized to either alleviate bleaching stress and provide an alternative source of $\mathrm{N}$, compensating for a reduced translocation of $\mathrm{N}$ from Symbiodiniaceae to the host $[9,19,20]$, or to actually disrupt the coral symbiosis and trigger bleaching by changing the nutrient supply

\footnotetext{
${ }^{1}$ Earth Observatory of Singapore, Interdisciplinary Graduate School, Nanyang Technological University, Singapore, Singapore. ${ }^{2}$ Asian School of the Environment, Nanyang Technological University, Singapore, Singapore. ${ }^{3}$ Earth Observatory of Singapore, Nanyang Technological University, Singapore, Singapore. ${ }^{4}$ American Museum of Natural History, New York, NY, USA. ${ }^{5}$ Singapore Centre for Environmental Life Sciences Engineering (SCELSE), Nanyang Technological University, Singapore, Singapore. ${ }^{6}$ Division for Ecology and Biodiversity, School of Biological Sciences, University of Hong Kong, Hong Kong, PR China. ${ }^{7}$ The Swire Institute of Marine Science, University of Hong Kong, Hong Kong, PR China. email: moyn0001@e.ntu.edu.sg
}

Received: 10 December 2020 Revised: 23 June 2021 Accepted: 30 June 2021

Published online: 22 July 2021 
ratio to Symbiodiniaceae $[24,25]$. Moreover, $\mathrm{N}_{2}$ fixation rates and diazotrophic community composition have only been jointly analyzed in the tissue of one tropical coral species from nutrientpoor waters [8]. Given the distinct differences in coral morphology and microbial community composition between coral species, as well as the wide range of environmental conditions under which coral reefs form, our understanding of this potentially important microbial process is limited.

The majority of coral-associated $\mathrm{N}_{2}$ fixation measurements have been made in subtropical, oligotrophic waters (e.g., Red Sea) using aquaria, with DIN concentrations ranging from 0.17 to $1.4 \mu \mathrm{M}$ and dissolved inorganic phosphorus (DIP) concentrations from 0.02 to $0.3 \mu \mathrm{M}$, when reported (Table S1). $\mathrm{N}_{2}$ fixation was thought to occur primarily in DIN-depleted waters [26, 27], with coral-associated diazotrophy increasing in response to seasonal oligotrophic conditions [15]. However, recent findings suggest that $\mathrm{N}_{2}$ fixation is likely underestimated in DIN-replete coastal waters [28-30] and that in some cases, nitrate may even enhance planktonic [31, 32] and coral-associated [33] diazotrophy. In addition, the ratio of DIN to DIP, which has rarely been reported in coral-diazotrophy studies (Table S1), may control $\mathrm{N}_{2}$ fixation more than the DIN concentration alone [34]. As coral reefs form within a range of nutrient conditions, it is critical to constrain rates of $\mathrm{N}_{2}$ fixation for a variety of reef settings, including reefs impacted by human activities and urbanization, as well as in understudied regions, such as Southeast Asia [6, 35, 36]. Moreover, all previous measurements of coralassociated $\mathrm{N}_{2}$ fixation have been performed in aquaria (Table S1). As coral microbial communities can change drastically within a day of aquarium captivity $[37,38]$, in situ studies are a critical next step toward fully understanding coral-associated $\mathrm{N}_{2}$ fixation.

Here, we performed 24-h incubations using reef-acclimated fragments of three hard coral species on two reefs in Singapore. Studies were conducted during the southwest monsoon, when nutrient concentrations are seasonally elevated. We measured rates of DDN assimilation into four separate coral compartments (host tissue, algal symbionts, released mucus, skeleton), and constrained the contribution of coral-associated $N_{2}$ fixation for both the holobiont and reef nitrogen budgets. Additionally, we analyzed the DNA- and RNA-based microbial community composition in both the coral tissue and the skeleton, using a multimarker metabarcoding approach. As RNA has a shorter lifespan than DNA, comparison of RNA and DNA can be used to gain insight into the relative activity of taxonomic groups and biogeochemical processes that scale with cell production [39-43]. Using RNA:DNA ratios, we examine the relative activity of key taxa between coral species and compartments, in relation to isotopic $\mathrm{N}_{2}$ fixation rate measurements.

\section{MATERIALS AND METHODS \\ Sample collection and incubation}

Corals were sampled at Pulau Hantu $\left(1^{\circ} 13^{\prime} 38.6 \mathrm{~N}, 103^{\circ} 44^{\prime} 48.1 \mathrm{E}\right)$ and Kusu Island $\left(1^{\circ} 13^{\prime} 31.6 \mathrm{~N} 103^{\circ} 51^{\prime} 37.5 \mathrm{E}\right)$, Singapore (Fig. S1) at 3-5 m depth. Two species were used at each site (Kusu: Pocillopora acuta and Platygyra sinensis; Hantu: Goniopora columna and Platygyra sinensis) and are referred to throughout the text by their genus. Species were selected based on trophic position and relative abundance at each reef. Benthic cover data were compiled from recent studies [44, 45]. Per species per site, four colonies were fragmented underwater into pieces with $\sim 30 \mathrm{~cm}^{2}$ of living tissue surface area. Two fragments per colony $(n=32)$ were attached to an underwater rig at $\sim 4 \mathrm{~m}$ depth using cable ties and allowed to acclimate for 1 week. Of these fragment pairs, one fragment from each colony was incubated in enriched water and the other in unenriched water. At the time of fragmentation, additional samples were collected from each colony, stored on ice, and then stored at $-20^{\circ} \mathrm{C}(n=16)$. These fragments were used to determine baseline isotopic signatures to detect any effect of fragmentation and acclimatization on individual coral colonies.

Incubations were performed with dissolved ${ }^{15} \mathrm{~N}_{2}$ gas [17]. Prior to each experiment, $\sim 80 \mathrm{I}$ of surface water were collected from each reef and filtered sequentially through GF/F (Whatman-1825-047) and $0.2 \mu \mathrm{m}$ cellulose acetate filters (Whatman-7001-0004). This filtered water was used in coral incubations, filter-sterilized controls, and to prepare the ${ }^{15} \mathrm{~N}_{2}$ label. The ${ }^{15} \mathrm{~N}_{2}$ label (Cambridge Isotopes) was prepared following Klawonn et al. [46] (see Supplementary Information), achieving a final enrichment $>90 \%{ }^{15} \mathrm{~N}_{2}$.

Four ${ }^{15} \mathrm{~N}_{2}$ enriched and four unenriched incubations were performed per species per site (32 total coral incubations). Prior to incubation, fragments were attached to clean PVC holders with new cable ties and rinsed briefly with filter-sterilized seawater. As enrichment controls, filtered-sterilized seawater was enriched and incubated in triplicate. Using a Niskin bottle, seawater was collected on the day of the experiment at $5 \mathrm{~m}$ depth, the approximate depth of the reef, and was enriched and incubated in triplicate to measure water column $\mathrm{N}_{2}$ fixation. All incubations were performed in 1 I glass jars with Teflon-lined lids (Wheaton-Z263486). Jars were sealed, headspace-free, while submerged in water, and $100 \mathrm{ml}$ of predissolved ${ }^{15} \mathrm{~N}_{2}$ tracer $\left(>90 \%{ }^{15} \mathrm{~N}_{2}\right.$, described above) were injected into enriched incubations via septa to achieve a final enrichment of 8.5-11.5\% ${ }^{15} \mathrm{~N}_{2}$. A separate septum and needle were used as an outflow while injecting the labeled water. The enrichment in each incubation jar was measured directly, as described below. Prior to deployment, dissolved oxygen was measured in each jar (Unisens-OXY1-SMA).

Jars were attached to crates and incubated on the reef for $24 \mathrm{~h}$ ( 13:00-13:00) (Fig. S2). After retrieval, collection and filtration of both seawater and coral samples were performed immediately aboard the boat. In each jar, dissolved oxygen was measured and seawater was sampled for atom $\%{ }^{15} \mathrm{~N}_{2}$, using He-flushed Exetainers (Labco-938W) with $10 \mu \mathrm{l} 50 \%$ wt/ vol $\mathrm{ZnCl}_{2}$ per $\mathrm{ml}$ of sample as a preservative. The remaining seawater in each jar was then filtered onto pre-combusted, pre-weighed GF/F filters for isotopic analysis of coral mucus released into the water during the incubation $[19,47]$, referred to as "released mucus". With a pore size of $0.7 \mu \mathrm{M}, \mathrm{GF} / \mathrm{F}$ filters capture mucus aggregates, but may miss smaller, nonaggregated cells [48]. Each coral fragment was photographed for photogrammetric surface area measurements (Autodesk-ReCap Photo), and then split into subsamples using a sterilized chisel. Approximately $1 / 4$ of each coral was flash-frozen in a dry shipper and stored at $-80^{\circ} \mathrm{C}$ for molecular analysis, and the rest was transported on ice and stored at $-20^{\circ} \mathrm{C}$ for isotopic analysis.

A Niskin bottle was used to collect additional seawater samples $(5 \mathrm{~m}$ depth). In total, 1 I was filtered onto a $0.22 \mu \mathrm{m}$ filter to sample the water column microbial community (Sterivex-SVGP01050), and 11 was filtered onto pre-combusted, pre-weighed GF/F filters to measure particulate $\delta^{15} \mathrm{~N}$ and $\delta^{13} \mathrm{C}$. Samples for dissolved inorganic nutrients were filtered through $0.22 \mu \mathrm{m}$ polyethersulfone syringe filters (Pall-4612) into acid-washed $15 \mathrm{ml}$ tubes. Seawater samples were flash-frozen in a dry shipper and stored at $-80^{\circ} \mathrm{C}$ (microbial) and $-20^{\circ} \mathrm{C}$ (nutrients) until analysis.

\section{Isotope analysis}

Isotopic analysis was performed on four coral compartments: host tissue, algal symbionts, released mucus, and skeleton. Coral tissue for isotope analysis was thoroughly removed with ultrapure water

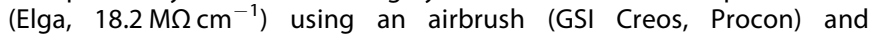
homogenized with a rotor-stator tissue homogenizer (BioSpec-98537014). The homogenate was centrifuged at $700 \mathrm{rcf}$, separating the algal pellet (symbiont) from the supernatant (host). The supernatant was spun at $3000 \mathrm{rcf}$ to further purify the coral host tissue and pellet any remaining symbiont fraction. After the initial separation, the symbiont pellet was rinsed twice with ultrapure water at $1500 \mathrm{rcf}$ and once at 2000 rcf. Tissue was freeze-dried, weighed in silver capsules (Sercon-SC0035), and acidified with $6 \mathrm{~N} \mathrm{HCl}$ prior to analysis (Thermo Scientific-TS-24308). After tissue removal, remaining tissueless skeletons were dried at $60^{\circ} \mathrm{C}$ for $48 \mathrm{~h}$. The endolithic layer (Fig. S2b) was removed from tissueless samples using a Dremel tool and a diamond disc. Care was taken to remove the upper portion of the skeleton, particularly in Platygyra samples, by "skimming" this uppermost portion off the skeleton. Endolithic samples were cryopulverized (BioSpec-59014N), dried at $60^{\circ}$ $\mathrm{C}$ for $24 \mathrm{~h}$, and weighed into tin capsules (Sercon-SC0148). Filters with released coral mucus and seawater particulate matter were dried at $60^{\circ} \mathrm{C}$ for $24 \mathrm{~h}$, weighed, and folded into tin capsules.

Particulate isotope samples were analyzed using a Eurovector Elemental Analyzer and Nu Instruments Perspective Isotope Ratio Mass Spectrometer at the University of Hong Kong. Instrumental error was $<0.16 \%$ and determined using an in-house acetanilide standard (iACET), certified by Indiana University. $\delta^{15} \mathrm{~N}$ and $\delta^{13} \mathrm{C}$ values were determined using Eqs. (1) 
and (2):

$\delta^{15} \mathrm{~N}(\%)=\left[\frac{R_{\text {sample }}}{R_{\text {air }}}-1\right] \times 1000$

$\delta^{13} \mathrm{C}(\% 0)=\left[\frac{R_{\text {sample }}}{R_{\mathrm{PDB}}}-1\right] \times 1000$

where $R_{\text {sample }}=\left({ }^{15} \mathrm{~N} /{ }^{14} \mathrm{~N}\right)$ and $R_{\text {air }}=0.003676$ for $\mathrm{N}$ isotopes, and $R_{\text {sample }}=\left({ }^{13} \mathrm{C} /{ }^{12} \mathrm{C}\right)$ and $R_{\mathrm{PDB}}=0.011180$ for $\mathrm{C}$ isotopes. $\delta^{15} \mathrm{~N}$ was converted to atom\% $(A)$ using Eq. (3) [18]:

$A=$ atom $\%{ }^{15} \mathrm{~N}=100 \times \frac{{ }^{15} \mathrm{~N}}{{ }^{15} \mathrm{~N}+{ }^{14} \mathrm{~N}}=100 \times \frac{R_{\mathrm{air}} \times\left(\delta^{15} \mathrm{~N} \times 0.001+1\right)}{1+R_{\text {air }} \times\left(\delta^{15} \mathrm{~N} \times 0.001+1\right)}$

with R 4.0.2 [49], compartment- and species-specific paired t-tests were used to test for any effect of fragmentation and acclimatization on the isotopic signatures of corals. Isotopic results between species and sites were compared with unpaired $t$-tests. Shapiro-Wilk tests were used to check for normality.

Atom\% of dissolved ${ }^{15} \mathrm{~N}_{2}$ was measured at the University of California Davis using a GasBench and Precon gas concentration system interfaced to an isotope-ratio mass spectrometer. Dissolved ${ }^{15} \mathrm{~N}_{2}$ measurements were performed for each enriched incubation chamber and in non-enriched seawater.

\section{Calculation of $\mathbf{N}_{\mathbf{2}}$ fixation rate}

To determine $\mathrm{N}_{2}$ fixation rates, particulate atom $\%{ }^{15} \mathrm{~N}$ from paired enriched $\left(A_{\mathrm{e}}\right)$ and control $\left(A_{\mathrm{c}}\right)$ replicate samples were subtracted for each fraction (i.e., host tissue, algal symbionts, released mucus, skeleton, and seawater). Detectable $\mathrm{N}_{2}$ fixation was defined as when the difference between $\left(A_{\mathrm{e}}\right)$ and $\left(A_{c}\right)$ was greater than $3 x$ the standard deviation of repeated $A_{c}$ measurements, following $[19,47,48]$. Rates below the detection limit were assumed to be zero when calculating average rates, resulting in more conservative estimates (see Supplementary Information). DDN $\mathrm{Dasmilation}_{\text {was }}$ determined following Eq. (4) [18]:

$\mathrm{DDN}_{\text {assimilation }}=\frac{1}{\Delta t} \frac{A_{\mathrm{e}}-A_{\mathrm{c}}}{A_{15 \mathrm{~N} 2}-A_{\mathrm{o}}} \times[\mathrm{PN}]$

where $\left(A_{\mathrm{e}}-A_{\mathrm{c}}\right)$ is the particulate difference in atom\%, $A_{15 \mathrm{~N} 2}$ is the atom $\%{ }^{15} \mathrm{~N}$ of each labeled incubation, $A_{\circ}$ is the atom\% ${ }^{15} \mathrm{~N}$ of unlabeled seawater, and [PN] is the particulate nitrogen concentration. [PN] was determined from the $\% \mathrm{~N}$ of the enriched sample. Rates were standardized by dry weight (DW), surface area, and/or volume, according to the sample type (see Supplementary Information refs. [4-6]).

\section{Water column chemistry}

Dissolved nutrients were measured using a SEAL AA3 autoanalyzer following standard methods [50]. The detection limits were 0.05, 0.03, 0.12 , and $0.10 \mu \mathrm{M}$ for $\mathrm{NO}_{x}, \mathrm{PO}_{3-}^{4}, \mathrm{NH}^{+}{ }_{4}$, and $\mathrm{Si}(\mathrm{OH})_{4}$, respectively. DIN is taken as $\left[\mathrm{NO}_{x}\right]+\left[\mathrm{NH}_{4}^{+}\right]$. DIP is $\left[\mathrm{PO}_{3}^{4}{ }^{-}\right]$. Temperature, salinity, and chlorophyll-a at the incubation site were measured using a Valeport FastCTD profiler with chlorophyll fluorometer. Photosynthetically active radiation (PAR) was measured during a concurrent experiment [51], 1 $\mathrm{m}$ shallower than the incubation experiment.

Nucleic acid extraction, PCR, sequencing, and bioinformatics For nucleic acid extraction, coral tissue (host and symbiont) was removed with an autoclaved, $0.22 \mu \mathrm{m}$-filtered 1x PBS, $10 \mu \mathrm{M}$ EDTA solution using an airbrush and homogenized with a rotor-stator tissue homogenizer. The coral skeletons were cryopulverized. Tissue and skeletal samples were aliquoted for DNA and RNA extractions. Detailed protocols of sample preparation, nucleic acid extractions, and PCR conditions are reported in the Supplementary Information.

PCR was performed using the following primer sets: $16 \mathrm{~S}$ rRNA (V6-V8 hypervariable region), B969F 5'- ACGCGHNRAACCTTACC-3' and BA1406 5'ACGGGCRGTGWGTRCAA-3' [52] (cf. [53-55]); nitrogenase iron protein (nifH), IGK3 5'-GCIWTHTAYGGIAARGGIGGIATHGGIAA-3' and DVV 5'-ATIGCRAAICCICCRCAIACIACRTC-3' [56]; 18S rRNA (V4 hypervariable region) (coral samples) UNonMet-F 5'-GTGCCAGCAGCCGCG-3' and UNonMet-R $5^{\prime}$ TITAAGTTTCAGCCTTGCG-3' [57], followed by V4-18S-For 5'-CCAGCASCYGCGGTAATTCC-3' and V4-18S-Rev 5'-ACTTTCGTTCTTGATYRATGA-3' [58]; and $18 \mathrm{~S}$ rRNA (seawater samples) V4-18S-For and V4-18S-Rev. Samples were purified, barcoded, and sequenced by the GeT-PlaGe platform of GenoToul (INRA Auzeville, France) using an Illumina MiSeq platform $(2 \times$ $250 \mathrm{bp})$.

Sequence data were processed in R 4.0.2 [49] using DADA2 [59, 60], as described in the Supplementary Information. For the 16S rRNA and 18S rRNA datasets, the SILVA 16 S rRNA database (v138) $[61,62]$ and the $P^{2}$ database (v4.12) [63] (https://pr2-database.org/) were used as training sets. For nifH, a new database was created in DADA2 format by modifying, updating, and reformatting the nifH June 2017 ARB database from Heller et al. [64]. Files, scripts, and documentation used in creating the nifH DADA2 database can be found at https://github.com/moyn413/nifHdada2 [65]. Sequences were submitted to the NCBI Sequence Read Archive (BioProject: PRJNA678423). Analyses were performed using the R Phyloseq [66] and DESEQ2 packages [67], Geneious Prime 2019.2.3 (https://www. geneious.com), and the Interactive Tree of Life [68]. Files and scripts are available at https://github.com/moyn413/Singapore-coral-microbes.

For 16S rRNA RNA:DNA ratios (16S RNA:DNA), normalized replicates were merged and ratios were determined for each ASV that appeared in both the RNA and DNA samples. Average RNA:DNA ratios of ASVs were determined within taxonomic orders for each coral species and compartment. Due to low replicate numbers in paired nifH RNA and DNA samples, coral species and compartment were not analyzed separately for nifH RNA: DNA ratios. As RNA:DNA ratios are known to have high variability within and between taxonomic groups $[40,42]$, ratios should be interpreted with caution.

\section{RESULTS}

\section{Site characterization}

DIN ranged from 2.80 to $3.48 \mu \mathrm{M}$, DIP from 0.21 to $0.23 \mu \mathrm{M}$, and chlorophyll-a from 0.53 to $0.97 \mu \mathrm{gl}^{-1}$ (Table S2). This exceeds eutrophication thresholds for coral reefs (DIN: $1 \mu \mathrm{M}$; phosphate: $0.1 \mu \mathrm{M}$; chlorophyll-a: $\left.0.4-0.5 \mu \mathrm{g} \mathrm{I}^{-1}[1,69]\right)$. The N:P ratio was 15.3 (Kusu) and 13.8 (Hantu), slightly below the Redfield ratio (16:1). Salinity $(29.6 \pm 0.5 \mathrm{psu})$ and temperature $\left(29.4 \pm 0.1^{\circ} \mathrm{C}\right)$ were consistent at both sites throughout the study period (Table S2). The PAR daily light integral was 12.08 mol photons $\mathrm{m}^{-2}$ per day (Hantu) and $19.02 \mathrm{~mol}$ photons $\mathrm{m}^{-2}$ per day (Kusu) on each incubation day [51]. Hantu had significantly lower live hard coral cover $(39.1 \pm 4.8 \%)$ than Kusu $(52.8 \pm 6.1 \%)$ [44] (Table S3). Goniopora dominated coral cover at Hantu (12.3\%), while Kusu reef had greater hard coral diversity and evenness, with no one species accounting for more than $4 \%$ of coral cover [45] (Table S3).

\section{Baseline isotope ratios and physiology}

The $\delta^{15} \mathrm{~N}$ and $\delta^{13} \mathrm{C}$ values of coral fragments collected directly from the reef (Baseline) did not differ from corresponding fragments in non-enriched control incubations (Control) for each species and site (Fig. 1a and Table S4) (paired $t$-tests, $p>0.05$ ), indicating that fragmentation and incubation did not affect the isotopic composition. Host tissue $\delta^{15} \mathrm{~N}$ from Platygyra was $\sim 1.6 \%$ more enriched than algal symbionts, whereas in Pocillopora and Goniopora, host tissue was $0.9 \%$ and $-0.05 \%$ more enriched than the algal symbionts, respectively (Fig. 1a). $\delta^{13} \mathrm{C}$ differed significantly between all corals (unpaired $t$-tests, $p<0.05$ ), and Platygyra from Hantu and Kusu were more ${ }^{13} \mathrm{C}$ enriched $(-14.3 \pm 1.0 \%$; $-15.6 \pm 0.6 \%$ o) than Goniopora and Pocillopora (-17.5 $\pm 0.5 \%$; $-19.8 \pm 0.4 \%$ ) (Fig. S3). Based on $\delta^{15} \mathrm{~N}$ and $\delta^{13} \mathrm{C}$ results, Platygyra was relatively more heterotrophic while Pocillopora and Goniopora were more autotrophic [70]. These trophic positions were stable over a 2-year period (2017-2019) at the same sites, with host tissue $\delta^{15} \mathrm{~N}$ greater than symbiont $\delta^{15} \mathrm{~N}$ by an average of $1.77 \pm$ $0.97 \%$ o (Platygyra-Hantu), $-0.38 \pm 0.34 \%$ o (Goniopora-Hantu), $1.57 \pm$ $0.78 \%$ o Platygyra-Kusu), and $0.09 \pm 0.90 \%$ (Pocillopora-Kusu) (Moynihan, unpublished data). The $\mathrm{C}: \mathrm{N}$ ratio of host tissue and algal symbionts was lower than that of the released mucus in both Kusu species (unpaired $t$-tests, $p<0.05$ ) and in Platygyra from Hantu (unpaired $t$-test, $p=0.06$ ) (Fig. $1 \mathrm{~b}$ ). In contrast, the $\mathrm{C}: \mathrm{N}$ ratio of Goniopora tissue (host and symbiont) did not differ from that of the 

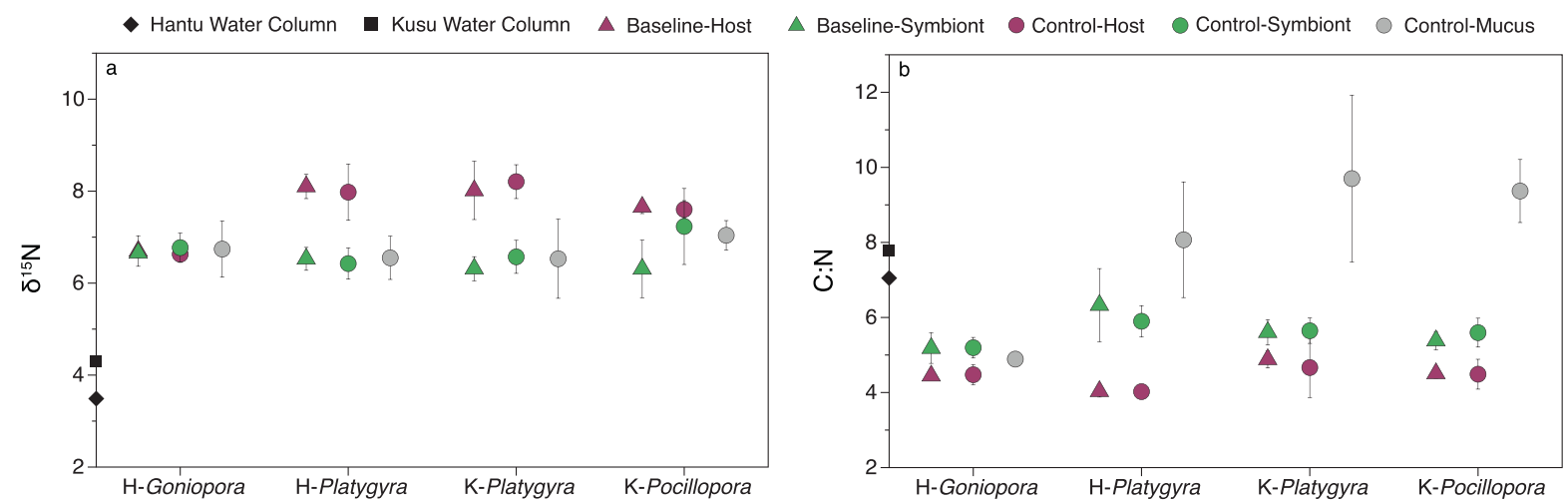

Fig. 1 Comparison of $\delta^{15} \mathrm{~N}$ values and C:N ratios from Baseline and Control samples. Baseline and Control a $\delta^{15} \mathrm{~N}$ and $\mathbf{b} \mathrm{C}: \mathrm{N}$ of coral host tissue, algal symbionts, and released mucus are plotted alongside water column particulate organic matter $\delta^{15} \mathrm{~N}$ and $\mathrm{C}: \mathrm{N}$ from incubation dates. Released coral mucus samples are from Control incubations only.

released mucus and was lower than all other samples (unpaired $t$ tests, $p<0.05)$.

With the exception of Pocillopora, oxygen concentrations decreased in most coral incubations, with average net change in $\left[\mathrm{O}_{2}\right]$ of $-3.5 \mathrm{mg} \mathrm{I}^{-1}$ (Hantu-Goniopora), $-1.8 \mathrm{mg} \mathrm{I}^{-1}$ (Hantu-Platygyra), $-0.9 \mathrm{mg} \mathrm{I}^{-1}$ (Kusu-Platygyra), and $+0.2 \mathrm{mg} \mathrm{I}^{-1}$ (Kusu-Pocillopora). One ${ }^{15} \mathrm{~N}_{2}$ labeled Goniopora replicate experienced anoxia $\left(0.22 \mathrm{mg} \mathrm{O}_{2} \mathrm{I}^{-1}\right)$ (Fig. S4).

\section{$\mathbf{N}_{2}$ fixation}

Coral $\mathrm{N}_{2}$ fixation. High heterogeneity was observed between replicate samples, with 1-3 out of 4 replicates per species having detectable DDN in each compartment (Table S5). When standardized by surface area, DDN assimilation rates were highest in the endolithic skeletal compartment (Fig. 2a), ranging from 0 to $8.3 \mathrm{ng}$ $\mathrm{N} \mathrm{cm}^{-2} \mathrm{~h}^{-1}$. Symbiont DDN assimilation ranged from $0-0.32 \mathrm{ng} \mathrm{N}$ $\mathrm{cm}^{-2} \mathrm{~h}^{-1}$, and accounted for the majority of non-skeletal assimilation in Platygyra and Pocillopora. Host assimilation ranged from 0 to $0.45 \mathrm{ng} \mathrm{N} \mathrm{cm}^{-2} \mathrm{~h}^{-1}$, and accounted for the majority of non-skeletal assimilation in Goniopora. Released mucus assimilation accounted for the least DDN of all compartments in all species (range: $0-0.02 \mathrm{ng} \mathrm{N} \mathrm{cm}^{-2} \mathrm{~h}^{-1}$ ) (Fig. 2b). Normalizing DDN assimilation rates to DW changed relative assimilation rates in the compartments owing to differences in densities between the coral tissue and skeleton. Although not quantified here or in similar studies $[9,23]$, it would be more accurate to standardize endolithic rates by the skeletal organic content for comparison with other compartments. Normalized to DW, DDN assimilation was greater in the symbiont, released mucus, and host tissue compartments compared to the skeleton (Fig. 2c). $\mathrm{N}_{2}$ fixation rates in the released coral mucus were variable but similar to those of the water column (Fig. 2d).

To assess the relevance of these rates for coral nutrition, we estimated the holobiont $\mathrm{N}$ demand based on the total $\mathrm{N}$ content of bulk tissue and endolithic layer, assuming a tissue growth rate of $0.2 \%$ of DW per day, as reported for coral tissue in low-light environments [71, 72]. Endolithic growth rates are likely lower than tissue growth rates [73], which means that our calculation likely overestimated endolithic $\mathrm{N}$ demand. Considering the maximum DDN assimilation rates from all four compartments (host tissue, algal symbionts, released mucus, skeleton), $\mathrm{N}_{2}$ fixation could account for up to $2.9-6.4 \%$ of the total holobiont $\mathrm{N}$ demand (Table 1). When skeletal $\mathrm{N}_{2}$ fixation is excluded, the remaining $\mathrm{N}_{2}$ fixation accounted for $<3 \%$ of $\mathrm{N}$ demand. If all fixed nitrogen in the skeleton were translocated to the tissue above, this could meet up to $5.6-32.5 \%$ of the tissue $\mathrm{N}$ demand.

Water column and reef $\mathrm{N}_{2}$ fixation budget. Water column $\mathrm{N}_{2}$ fixation rates were normalized to dry mass, for comparison with mucus- associated fixation rates, and ranged from 2.5 to $9.3 \mathrm{ng} \mathrm{N} \mathrm{g}^{-1} \mathrm{~h}^{-1}$ (0.04-0.1 ng N I $\mathrm{h}^{-1}$ ) (Fig. 2d). Assuming a mucus-associated $\mathrm{N}_{2}$ fixation rate of $0.005 \mathrm{ng} \mathrm{N} \mathrm{cm}^{-2} \mathrm{~h}^{-1}$, as typical for our sites and species, released coral mucus DDN could add $0.06-0.08 \mathrm{nmol} \mathrm{I}^{-1}$ of nitrogen to the water column per day, given the estimated areal coral cover (Table S6). Water column $\mathrm{N}_{2}$ fixation contributed 0.14 and $0.12 \mathrm{nmolI}^{-1}$ of nitrogen per day at Hantu and Kusu, respectively. While these rates are low, mucus-associated $\mathrm{N}_{2}$ fixation at Hantu and Kusu represented $44-67 \%$ of the water column $\mathrm{N}_{2}$ fixation (Table S6).

\section{Coral microbial community}

In the 16S rRNA community, all alpha diversity indices were greater in the coral tissue (host and symbiont) than the endolithic skeleton compartment (Table S7). The DNA-based communities of Hantu-Goniopora and Kusu-Platygyra tissues were significantly more diverse than that of their skeletons, as well as the RNA-based community of Platygyra (Kusu) (unpaired $t$-tests, $p<0.05$ ). Coral species influenced the 16S rRNA microbial community composition more than sample type (i.e., tissue or skeleton) (Fig. 3a). However, within each species, significant differences were observed between tissue and skeletal communities (PERMANOVA-Adonis) (Kusu-Pocillopora, $R^{2}=0.41, p=0.001$; Kusu-Platygyra, $R^{2}=0.30, p=0.004$; Hantu-Platygyra, $R^{2}=0.31, p=0.004$; Hantu-Goniopora, $R^{2}=0.38, p=0.01$ ) (Fig. 3b). Moreover, the DNA-based 16S rRNA community differed from the RNA-based $16 \mathrm{~S}$ rRNA community in all species (Kusu-Pocillopora, $R^{2}=0.13$, $p=0.02$; Kusu-Platygyra, $R^{2}=0.10, p=0.02$; Hantu-Platygyra, $R^{2}=$ $0.16, p=0.001$; Hantu-Goniopora, $R^{2}=0.27, p=0.001$ ) (Fig. $3 b$ ).

In DNA-based 16S rRNA communities, Alphaproteobacteria (Rhodobacterales, Rhizobiales) and Bacteroidia (Cytophagales, Flavobacteriales) were abundant, with the common coral-associated genus Ruegeria [74] accounting for 51\% of Rhodobacterales amplicon sequence variants (ASVs) (Figs. S5 and S6). Within the phylum Cyanobacteria, 78\% of ASVs belonged to the order Synechococcales. In RNA-based 16S rRNA communities, the relative percentages of Gammaproteobacteria, Deltaproteobacteria, Bacteroidia, and Cyanobacteria were higher, while the contribution of Alphaproteobacteria was lower (Figs. S5 and S6). Within the Alphaproteobacteria RNA-based community, Rhodobacterales, Rhodospirillales, Rhizobiales, and Kiloniellales were the most abundant orders, with Ruegeria accounting for only $18 \%$ of Rhodobacterales. Synechococcales and Pleurocapsales, and Oscillatoriales were the most abundant cyanobacterial ASVs in RNA samples, including the known $\mathrm{N}_{2}$-fixing filamentous taxa Hormoscilla and Trichodesium, as well as non-filamentous Pseudanabaenaceae and Xenococcaceae. Plastid 16S rRNA ASVs from the endolithic algae Ostreobium were highly abundant in Pocillopora skeletal samples (Fig. S7). 

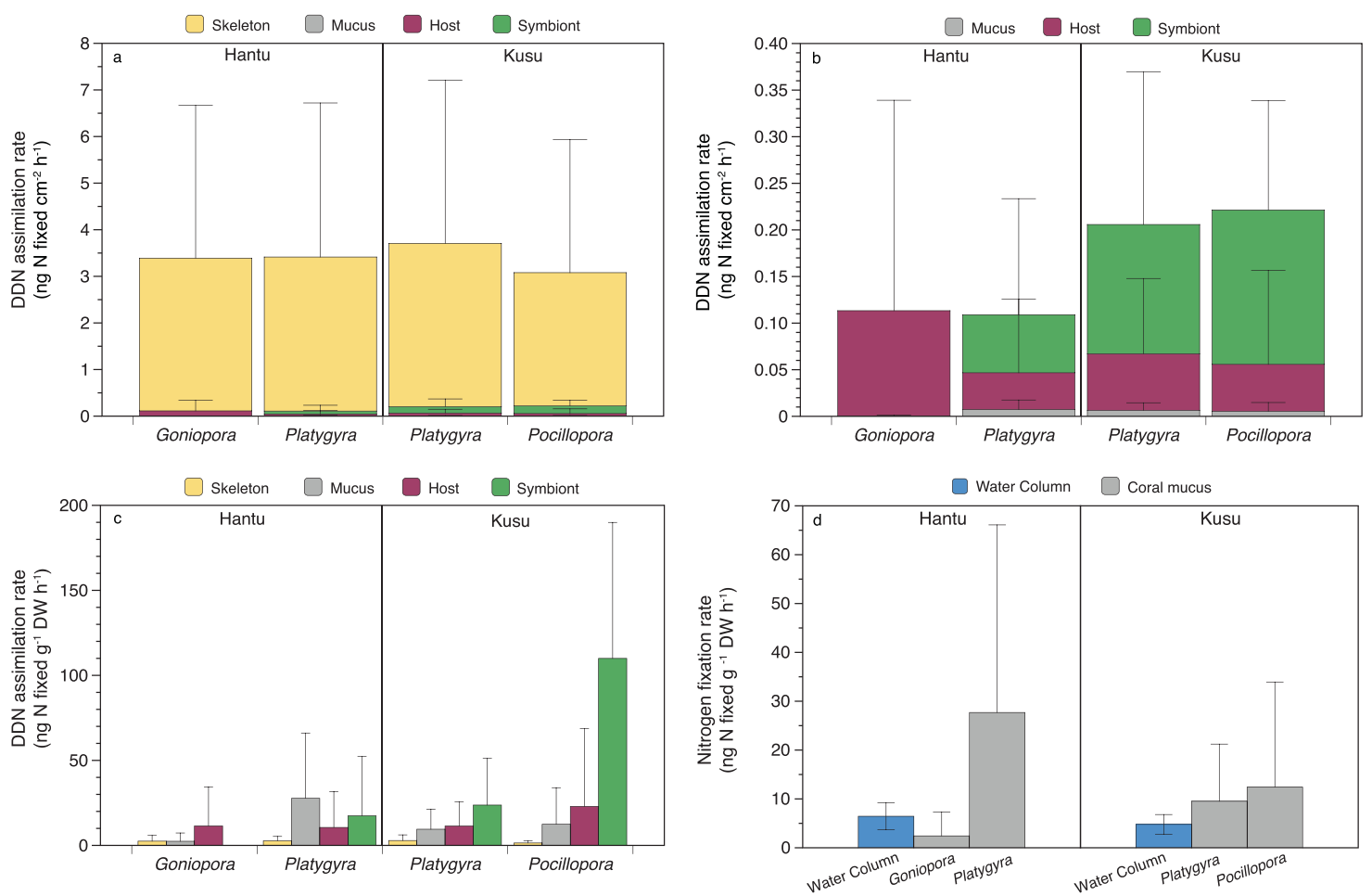

Fig. 2 Compartment-specific assimilation rates of diazotroph-derived nitrogen (DDN). DDN assimilation rates in the skeletal endolithic layer, host tissue, algal symbionts, and released mucus were standardized by a surface area ( $\mathrm{ng} \mathrm{N} \mathrm{cm} \mathrm{cm}^{-1}$ ), with the skeleton excluded in b, and $\mathrm{c}$ by dry weight (DW) ( $\mathrm{n} \mathrm{N} \mathrm{g}^{-1} \mathrm{DW} \mathrm{h}{ }^{-1}$ ). d Nitrogen fixation rates in released coral mucus and water column particulate organic matter, standardized by dry weight $\left(\mathrm{ng} \mathrm{N} \mathrm{g}^{-1} \mathrm{DW} \mathrm{h}^{-1}\right)$. Error bars represent the standard deviation in all panels.

Table 1. $\mathrm{N}_{2}$ fixation as a function of daily nitrogen $(\mathrm{N})$ demand.

\begin{tabular}{|c|c|c|c|c|}
\hline \multirow[t]{2}{*}{ Coral growth $\mathrm{N}$ budget } & \multicolumn{2}{|l|}{ Hantu } & \multicolumn{2}{|l|}{ Kusu } \\
\hline & Goniopora & Platygyra & Platygyra & Pocillopora \\
\hline Tissue $\mathrm{N}$ content $\left(\mathrm{mg} \mathrm{N} \mathrm{cm}^{-2}\right.$ ) & $1.85 \pm 0.50$ & $0.62 \pm 0.27$ & $0.49 \pm 0.12$ & $0.26 \pm 0.09$ \\
\hline Total $\mathrm{N}_{2}$ fixation/Total $\mathrm{N}$ demand & $2.89 \%$ & $3.72 \%$ & $3.51 \%$ & $6.45 \%$ \\
\hline Tissue $\mathrm{N}_{2}$ fixation/Tissue $\mathrm{N}$ demand & $0.29 \%$ & $0.83 \%$ & $1.25 \%$ & $2.22 \%$ \\
\hline Skeletal $\mathrm{N}_{2}$ fixation/Skeletal $\mathrm{N}$ demand & $5.62 \%$ & $4.89 \%$ & $4.01 \%$ & $7.49 \%$ \\
\hline
\end{tabular}

Tissue and skeletal $\mathrm{N}$ demand were both assumed to be $0.2 \%$ dry weight per day, as reported for coral tissue in low-light environments [71, 72]. Skeletal content includes both organic and inorganic nitrogen. Maximum $\mathrm{N}_{2}$ fixation rates from the skeleton and tissue (host, symbiont, mucus) were used in calculations.

Using a UNonMet and 18S rRNA nested primer approach [57], the $18 \mathrm{~S}$ community was primarily composed of Symbiodiniaceae; only 81 of 1216 taxa were metazoan. Symbiodiniaceae Clade D/E was the dominant clade in Pocillopora and Goniopora, and Clade C was dominant in Platygyra from both sites (Fig. S8). For the $18 \mathrm{~S}$ rRNA region sequenced, Clade $D / E$ cannot be distinguished. Communities differed between species (PERMANOVA-Adonis, $R^{2}=0.66, p=0.001$ ) (Fig. S9) and the average alpha diversity was greater in the skeleton than tissue in RNA-based community samples (unpaired $t$-test, $p=0.01$ ). Aside from Symbiodiniaceae, the most abundant microeukaryotes were Bacillariophyta (diatoms), Apicomplexa (parasitic alveolates), Spirotrichea (ciliates), and Ascomycota (fungi) (Fig. S10).

In the seawater community, Bacteria and Archaea were primarily Synechococcales, SAR11, SAR86, Flavobacteriales, Rhodobacterales, and Nitrosopumilales (Fig. S11). Plastid 16S and 18S rRNA sequences were dominated by the diatom genera
Skeletonema and Chaetoceros, green algae of the genera Osterococcus, Bathycoccus, and Micromonas, and dinoflagellates of the classes Syndiniophyceae and Dinophyceae (Fig. S12).

\section{Diazotrophic nifH community}

nifH ASVs were classified into six clusters [75]. Most ASVs belonged to Cluster $\mathrm{V}$, which contains nifH homologs involved in (bacterio) chlorophyll synthesis (bchL, bchX, ch/L) [76, 77] (Figs. 4 and S13). Within Cluster V, ASVs were closely associated with chloroplasts (notably, Ostreobium chloroplasts) or with Alphaproteobacteria (Rhizobiales, Rhodobacterales). Within Clusters I-III, which are known to fix nitrogen, Deltaproteobacteria, Gammaproteobacteria, and Cyanobacteria accounted for $86.5 \%$ of ASVs in the DNAbased community (Fig. 5).

The relative abundance of Clusters I-III ASVs differed between species (PERMANOVA-Adonis, $R^{2}=0.20, p=0.001$ ), but within each species, no difference was found between DNA-based tissue 

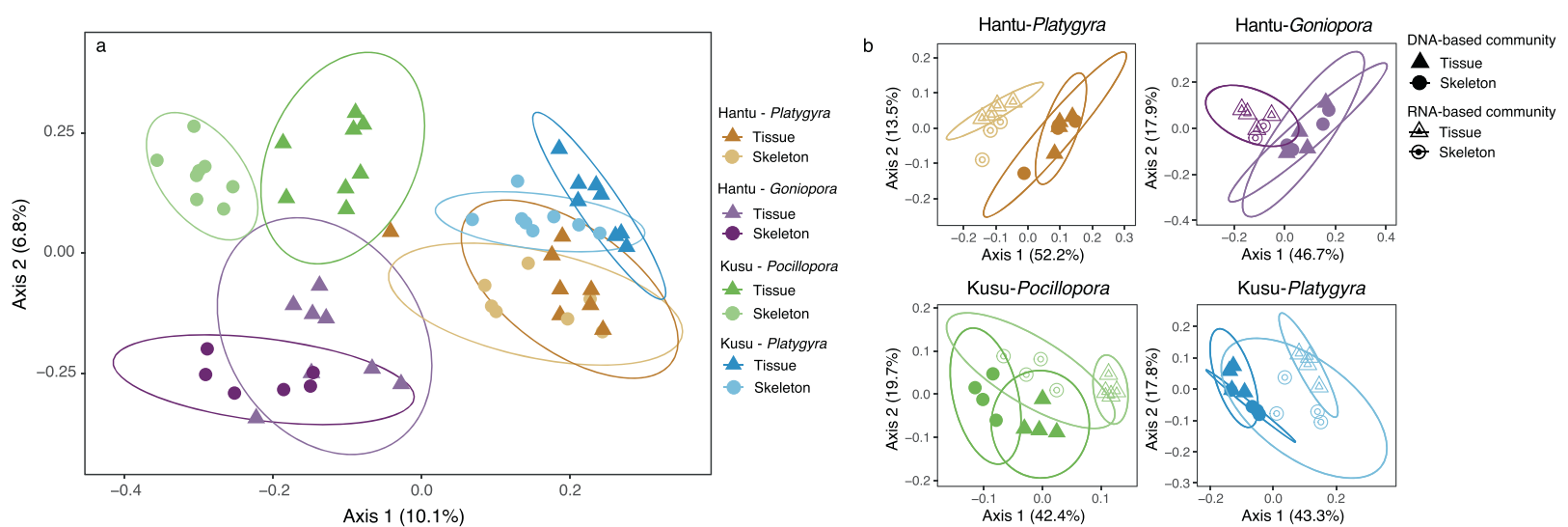

Fig. 3 Principal coordinates analysis (PCoA) of coral 16S rRNA microbial community composition. a PCoA of combined DNA-based and RNA-based communities, and $\mathbf{b}$ unifrac PCoA of 16S rRNA DNA-based and RNA-based community samples. Samples are colored by site and species, and shapes indicate tissue $(\triangle)$ or skeletal $(O)$ samples.

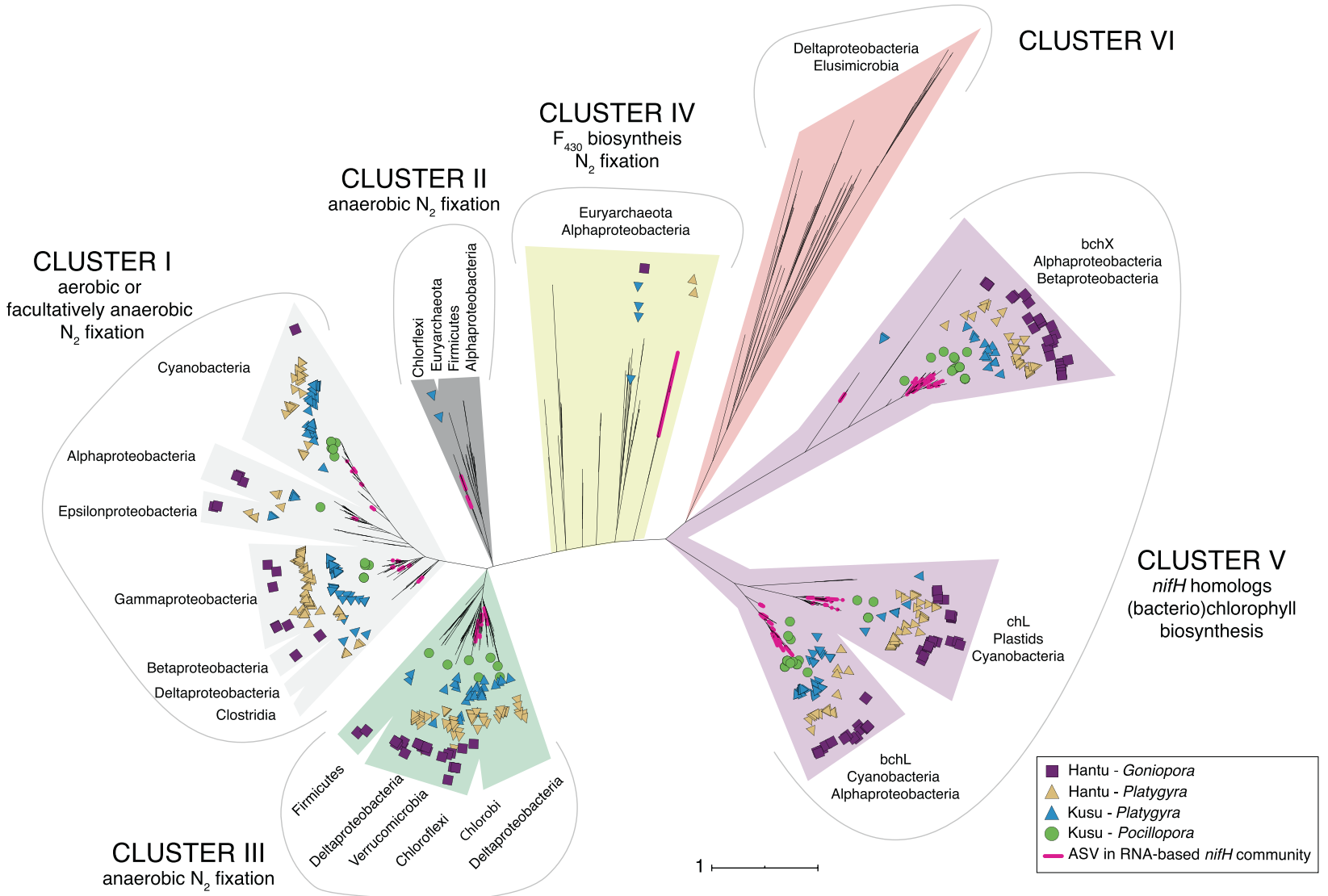

Fig. 4 Maximum-likelihood nifH phylogeny with ASVs from coral DNA and RNA samples, made using reference sequences from [75, 76], and [64] (see Supplementary Information for detail). ASVs from RNA-based community samples are pink, and ASVs from DNA samples are symbolized by ( $\bullet$ ) Hantu-Goniopora, ( $\triangle$ ) Hantu-Platygyra, ( $\Delta$ ) Kusu-Platygyra, and ( $\bullet$ ) Kusu-Pocillopora. Clusters I-III are known to fix nitrogen.

and skeletal communities (PERMANOVA-Adonis) $(p>0.05)$. Goniopora's diazotrophic community was primarily composed of Cluster III sulfate-reducing Deltaproteobacteria and had the lowest abundance of cyanobacterial nifH ASVs, which were absent from the tissue (Fig. 5). In Platygyra, Cyanobacteria, Gammaproteobacteria, Deltaproteobacteria, and Chloroflexi were the most abundant diazotrophs (Fig. 5), and Chloroflexi were more abundant in the skeleton relative to the tissue at both sites. The relative abundance of ASVs from Clusters I-III in Platygyra was 21.0\% at Hantu and $14.2 \%$ at Kusu. In Pocillopora, no nifH ASVs from Clusters I-III were found in the tissue, while Clusters I-III represented $<1 \%$ of the total nifH community in the skeleton (predominately Gammaproteobacteria and Cyanobacteria).

Due to practical and technical limitations, the RNA-based nifH community was only analyzed in $1 / 3$ of coral samples $(4 \times$ Platygyra and $3 \times$ Goniopora) (Fig. S14b). In the RNA-based 

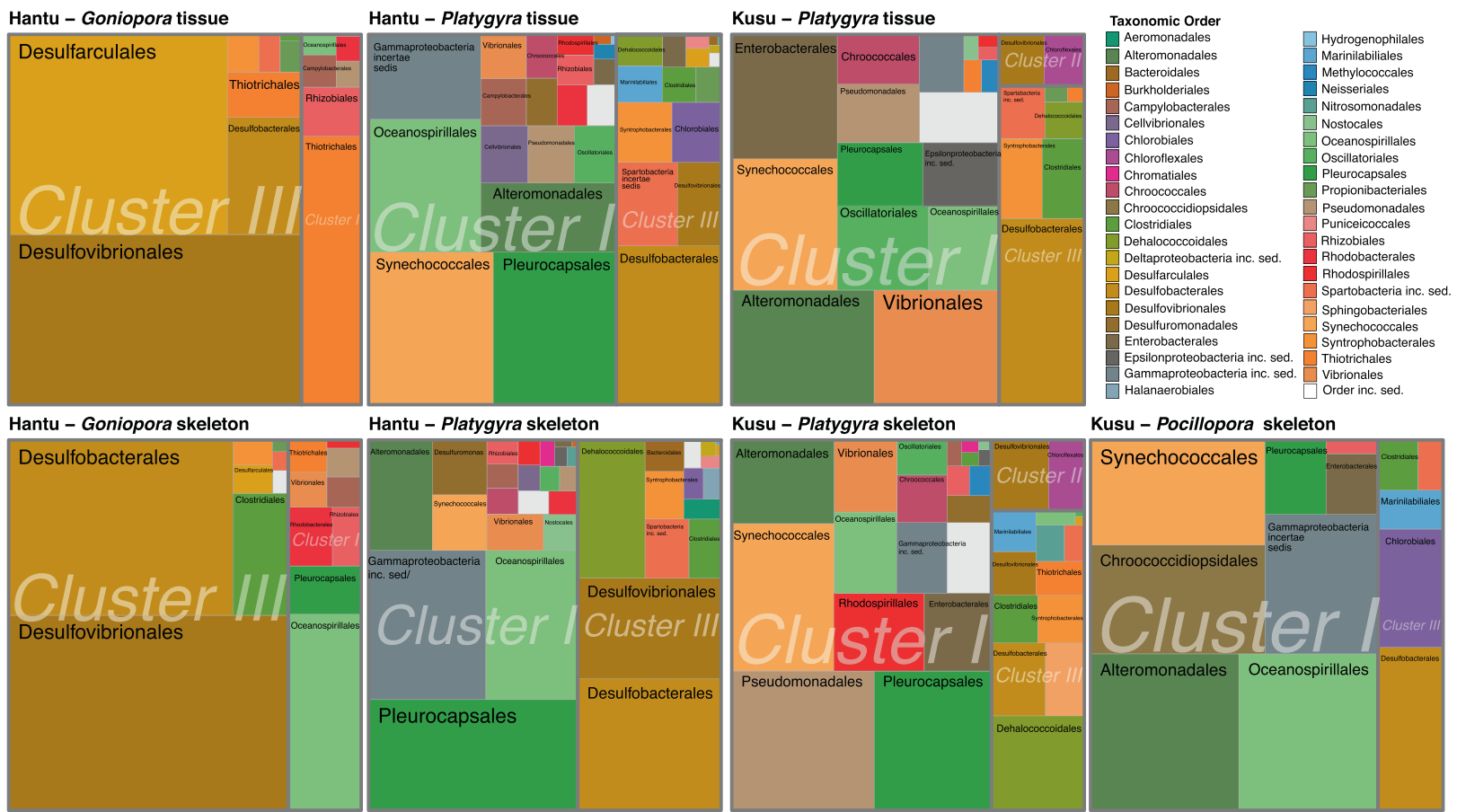

Hantu - Platygyra skeleton

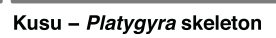

Kusu - Pocillopora skeleton
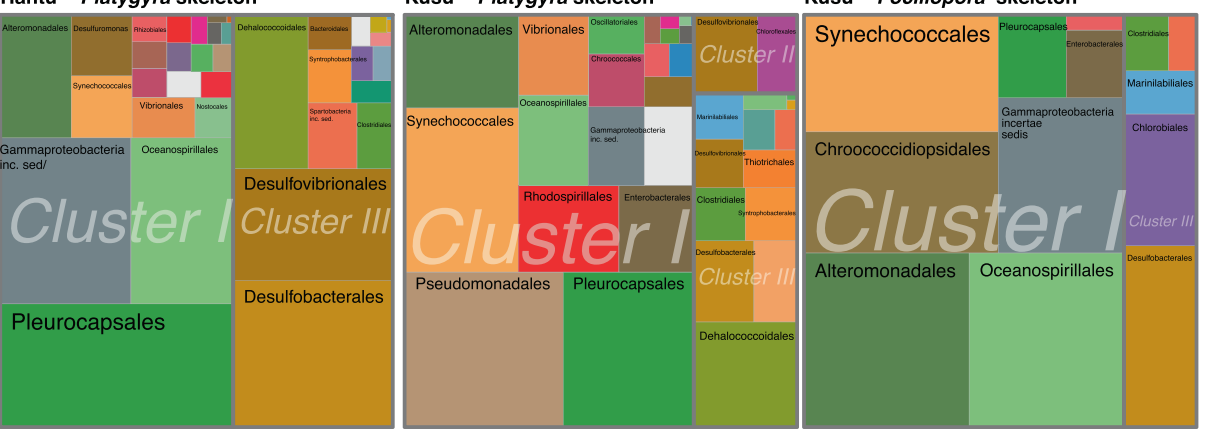

Fig. 5 Treemap of Clusters I-III ASVs of the nifH DNA-based community for each site, species, and site. Rectangles within each treemap are proportional to the relative abundance of each taxa. Taxa are nested within larger rectangles (separated by gray lines), representing the relative abundance of each cluster. Note that no Clusters I-III ASVs from Pocillopora tissue samples were identified.

community, Cluster I (aerobes or faculative anaerobes) had the highest relative abundance (Fig. S14b), accounting for $81.1 \%$ of Clusters I-III ASVs, including Synechococcales, Pleurocapsales, Oscillatoriales, Chloroflexales, Oceanospirillales, Alteromonadales, Vibrionales, Chromatiales, Desulfuromonadales, Rhizobiales, and Rhodospirillales.

In the water column, only three nifH ASVs known to fix nitrogen were found with raw abundances $>10$, and all were most closely related to Gammaproteobacteria from Cluster I. Although Cluster III ASVs were present in seawater samples, their raw abundances were all below the abundance threshold. The majority of nifH sequences from seawater were from Cluster $\mathrm{V}$, and related to Rhodobacterales (Hyphomonadaceae), Rhizobiales (Bradyrhizobiaceae), and red algal plastids.

\section{Coral tissue and skeletal relative microbial activity}

Taxonomic groups in the nifH community that differed between tissue and skeleton (DESEQ2 analysis) (Figs. 5 and 6) were analyzed for relative activity using RNA:DNA ratios (Fig. S15). As the $16 \mathrm{~S}$ rRNA-derived dataset had a higher number of RNA replicates than the nifH RNA-based dataset, skeleton and tissue comparisons were made with 16S rRNA data. Overall, patterns evident in 16S rRNA RNA:DNA ratios (16S RNA:DNA) between the skeleton and tissue were similar to patterns observed in the differential abundance (DESEQ2) analysis, suggesting both a change in abundance and relative activity of certain taxa within coral species and compartments. Cyanobacterial 16S RNA:DNA ratios indicated relative activity in both the tissue and skeleton (Fig. S15), particularly in both Platygyra species, where an 16S RNA: DNA ratio of 568.7 was observed for an ASV closely related to MBIC10086 of the family Pseudanabaenaceae. Synechococcales, which include $\mathrm{N}_{2}$-fixing taxa, were present in skeletal and tissue RNA and DNA samples from all species, except in Pocillopora tissue. For Goniopora, 16S RNA:DNA ratios of Synechococcales were $<1$, which is consistent with the low relative abundance of cyanobacteria in the nifH community of Goniopora. Greater relative activity and variability were observed in cyanobacterial ASVs in the skeleton (16S RNA:DNA $=20.5 \pm 95.6 \mathrm{SD}, n=35$ ) relative to the tissue (16S RNA:DNA $=4.7 \pm 10 \mathrm{SD}, n=55$ ). Additional taxonomic orders identified in the nifH cyanobacterial community also had high relative activity (16S RNA:DNA $>5$ ), including Pleurocapsales, Chroococcales, and Oscillatoriales (Figs. 5 and S15). Chloroflexi were relatively active in both the tissue and skeleton, and the majority of ASVs had greater relative activity in the skeleton $(8.2 \pm 31.3 \mathrm{SD}, n=34)$ in comparison with the tissue (3.6 \pm 3.9 SD, $n=12)$ (Fig. S15). Sulfate-reducing Deltaproteobacteria had similar 16S RNA:DNA relative activity in both the tissue $(5.9 \pm 9.6 \mathrm{SD}, n=18)$ and skeleton (3.8 $\pm 3.6 \mathrm{SD}, n=20)$. Among selected diazotrophic taxonomic groups, the majority of ASVs belonged to the class Alphaproteobacteria or Gammaproteobacteria, with an increased number of relatively active (16S RNA:DNA $>1$ ) selected Gammaproteobacterial ASVs in the tissue $(n=207)$ relative to the skeleton $(n=61)$, whereas the majority $(68 \%)$ of selected Alphaproteobacteria ASVs had an 16S RNA:DNA $<1$. Within Alphaproteobacteria, Rhodospirillales relative activity was highest (Fig. S15), with tissue 16S RNA:DNA exceeding skeletal 16S RNA:DNA, with ratios up to 43.8 (Goniopora tissue). Rhizobiales 16S RNA:DNA ratios were relatively low, with the exception of Goniopora where $\mathrm{N}_{2}$ fixing Pseudoxanthobacter had a ratio of up to 24.2 in the skeleton, whereas relatively active tissue-associated Rhizobiales were associated with a family of methanotrophs (Methyloligellaceae). Within Gammaproteobacteria, orders Oceanospirillales and Alteromonadales were abundant in the nifH community and also had elevated $16 \mathrm{~S}$ RNA:DNA ratios in the tissue and skeleton of all samples. Thiotrichales, which were abundant in the DNA-based nifH community of Goniopora, were also detected in Goniopora 16S RNA:DNA ratios.

RNA:DNA ratios of Clusters I-III nifH were analyzed for those samples where nifH RNA sequences were measured $(n=7)$. Similarly to the $16 \mathrm{~S}$ RNA:DNA, nifH RNA:DNA suggested relative 


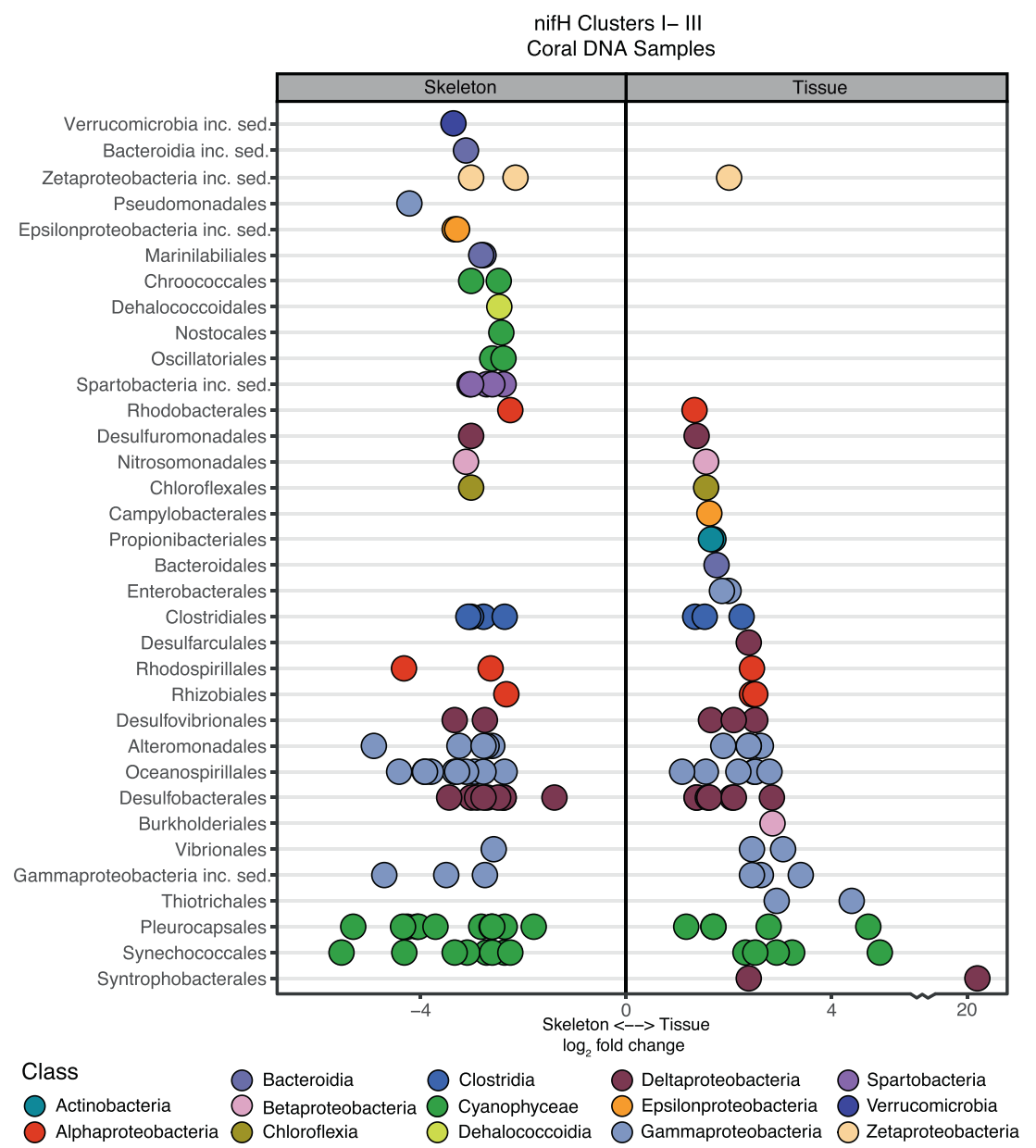

Fig. 6 Differential gene abundance analysis (DESEQ2) [113] of nifH ASVs from Clusters I to III, between the tissue and skeleton of coral samples. As Pocillopora had no nifH Clusters I-III ASVs in tissue sequences, it was excluded from this analysis. Results are plotted along a log 2 scale, with an axis break to include an ASV of the order Syntrophobacterales.

activity of ASVs of Synechococcales, Gammaproteobacteria (Oceanospirillales, Alteromonadales), and Chloroflexi (Fig. S16).

\section{DISCUSSION}

\section{Compartment-specific DDN assimilation}

DDN assimilation rates in coral host and symbiont compartments were within the low end of the range reported elsewhere (Fig. 7). Previous studies have reported up to 6.4-fold higher host DDN assimilation [9] (Fig. 7), as well as a large range in symbiont DDN assimilation from $0.002 \mu \mathrm{g} \mathrm{N} \mathrm{cm}^{-2}$ per day [78] to $11 \mu \mathrm{g} \mathrm{N} \mathrm{cm}^{-2}$ per day [14] in non-feeding, non-manipulated experiments (Fig. 7). DDN assimilation by released mucus was similar in magnitude to the majority of prior ${ }^{15} \mathrm{~N}_{2}$ mucus measurements $[9,16,47]$, with the exception of Bednarz et al. [19], where mucus DDN assimilation rates were over 200 -fold higher than those found in Singapore. Such high rates of mucus fixation could be a result of the dynamic nature of mucus microbial communities, which are influenced by the overlying water column $[79,80]$. In Bednarz et al. [19], the water column N:P ratio (1.5) was the lowest reported N:P of all Red Sea studies (Table S1) and 9.7-fold lower than in Singapore, which might have favored water column and mucusassociated diazotrophy.

In contrast with studies from the Coral Sea, which observed significantly higher rates of symbiont DDN assimilation relative to the host [8, 14], we observed slightly higher host than symbiont DDN assimilation, similar to $[19,78]$, which may be a result of regional and/or species-specific differences, as well as experimental design. As nutrient uptake rates are known to vary between the coral compartments [81, 82], the total incubation time may impact the compartment in which we observe fixed nitrogen. For example, in [19], significant mucus DDN assimilation was detected after $24 \mathrm{~h}$, whereas host and symbiont ${ }^{15} \mathrm{~N}_{2}$ assimilation was only detected after $72 \mathrm{~h}$. In contrast, some of the highest rates of DDN assimilation were measured in short, daytime experiments [14], and in one experiment, bulk tissue DDN assimilation was greater over a 12-h light period than a $24 \mathrm{~h}$ light/ dark period [23]. Consequently, variability in the length of coral incubations is likely to cause variability in compartment-specific DDN assimilation results, and ${ }^{15} \mathrm{~N}_{2}$ incubations of varying durations should be compared with caution. However, longer incubation times alone are unlikely to account for the multiple order of magnitude difference between symbiont DDN assimilation in Singapore and Coral Sea studies. Future work should seek to directly compare rate measurements and microbial communities with standardized methods across reefs.

Most DDN assimilation occurred within the skeletal compartment. While our skeletal DDN assimilation rates were several-fold higher than the two previous studies, these experiments only examined one temperate [78] and one subtropical coral [23] (Fig. 7). As $\mathrm{N}_{2}$ fixation measurements using the acetylene reduction assay (ARA) include endolithic fixation, our results suggest that endolithic diazotrophy may explain why ARA typically yields higher rates than ${ }^{15} \mathrm{~N}_{2}$ incubations (Fig. 7). Moreover, despite high N:P and DIN concentrations at the time of this study, total holobiont DDN assimilation was in the range of 


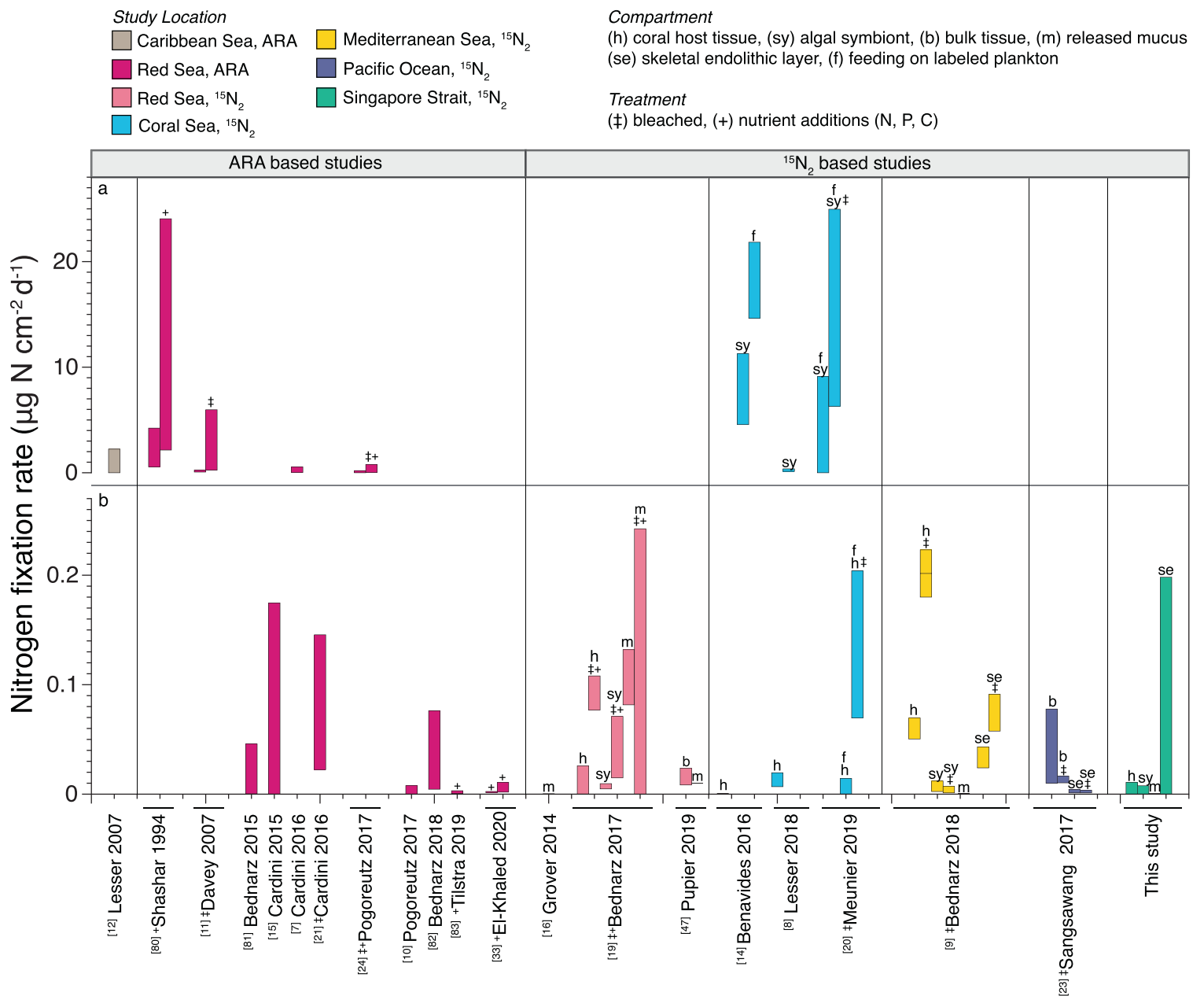

Fig. 7 Reported rates of coral-associated $\mathbf{N}_{2}$ fixation standardized to $\boldsymbol{\mu g} \mathbf{~ N ~ c m}^{-\mathbf{2}} \mathbf{d}^{-\mathbf{1}}$. $\mathrm{N}_{2}$ fixation rates are split into a $>0.25 \mu \mathrm{N} \mathrm{N} \mathrm{cm} \mathrm{c}^{-2} \mathrm{~d}^{-1}$, b $<0.25 \mu \mathrm{g} \mathrm{N} \mathrm{cm}^{-2} \mathrm{~d}^{-1}[7-12,14-16,19-21,23,24,33,47,78,109,114,115]$. The acetylene reduction assay (ARA) measures gross rates of $\mathrm{N}_{2}$ fixation in the entire coral holobiont. Studies using isotopic labeling $\left({ }^{15} \mathrm{~N}_{2}\right)$ measure net assimilation of fixed nitrogen $(\mathrm{N})$ in the specific tissue compartment analyzed (i.e., $m, h$, sy, b, f, se). All ARA results were multiplied by $2 / 3$ to convert from moles of $\mathrm{C}_{2} \mathrm{H}_{4}$ to moles of $\mathrm{N}$. Hourly rates were standardized to daily rates. Natural and experimentally manipulated rates are reported separately. ( $\neq)$ measurements are of bleached coral, and $\left(^{+}\right)$measurements are from experiments with manipulated $\mathrm{N}, \mathrm{P}$, or $\mathrm{C}$ nutrient concentrations.

previously reported ARA-based measurements. This finding is in agreement with recent work [33] that demonstrated an increase in coral-associated $\mathrm{N}_{2}$ fixation in response to eutrophication (Fig. 7). As the endolithic compartment is separated from the overlying water column by the coral tissue and mucus, endolithic microbial activity may be more sensitive to environmental changes in light $[81,83]$ than changes in nutrient concentrations, allowing high rates of $\mathrm{N}_{2}$ fixation activity to persist in eutrophic conditions. While it is unknown whether DDN from the endolithic region is transferred to the overlying coral tissue, experiments have shown that endolithic photoassimilates are transferred to coral tissue, and this transfer increases upon bleaching $[5,84]$. In addition, the endolithic community comprises a large percentage of the total holobiont in terms of both biomass and surface area [85-87] (Table 1). Given the high rate of endolithic DDN assimilation, it is possible that endoliths could be a source of nitrogen for coral tissue, or that this fixed nitrogen is incorporated into endolithic photoassimilates, which may be transferred to the coral tissue $[5,84]$. While our results cannot provide direct support for this hypothesis, endolithic, host, and symbiont compartments of Pocillopora contained fixed nitrogen, yet nifH ASVs from Clusters I-III were only found in its skeleton. Additionally, known diazotrophic taxa had higher 16S RNA:DNA-based activity in the skeleton than in the tissue of Pocillopora. However, direct evidence is needed to determine the potential role of endolithic-derived nutrients on the overlying coral tissue. Further experimental work, e.g., using isotope pulse-chase methods, would help to directly test the hypothesis that there is exchange of nitrogen between the coral host and endolithic community.

\section{Trophic position and diazotrophy}

Between sites, Platygyra showed a high degree of similarity in trophic position and the overall microbial community composition (Figs. 1, 3, and S9), supporting previous findings that corals form species-specific microbial associations [88, 89]. As trends in Platygyra DDN assimilation at both sites were also similar between compartments, DDN assimilation may also be highly speciesspecific. Between species, DDN assimilation rates were not related to coral trophic position, as inferred from our coral isotopic composition, which may explain different hypotheses regarding diazotrophy and trophic position [10, 19]. While Pocillopora and Goniopora exhibited similar trophic positions and had the same dominant clade of Symbiodiniaceae (Fig. S8), these two corals had drastically different diazotrophic communities, with Goniopora having a higher overall abundance of Clusters I-III ASVs, predominately anaerobic Cluster III ASVs. In Goniopora, DDN assimilation occurred mainly in the host and endolithic compartments, while in Pocillopora, the majority of DDN was assimilated in 
symbiont and endolithic compartments. These results may be related to morphological differences between the two species, rather than trophic position. Skeletal density and tissue thickness create different oxygen and light gradients, which are known to structure both tissue and endolithic communities [90-92]. Tissue thickness, endolithic biomass, and oxygen consumption were greatest in Goniopora, potentially creating more diverse diazotrophic niches. In contrast, Pocillopora had the lowest abundance of Cluster I-III nifH ASVs, along with the highest oxygen production, thinnest tissue, and lowest endolithic biomass, possibly creating fewer diazotrophic niches. Moreover, mucusassociated $\mathrm{N}_{2}$ fixation also differed between both autotrophic species by an average of five-fold. Previous work has proposed that high mucus $\mathrm{C}: \mathrm{N}$ leads to nitrogen limitation, favoring mucusassociated diazotrophy [47]. While our results follow this trend, with Pocillopora having higher released mucus $\mathrm{C}: \mathrm{N}$ and $\mathrm{N}_{2}$ fixation than Goniopora, only the C:N of released mucus differed significantly between the two species. Overall, differences in compartment-specific $\mathrm{N}_{2}$ fixation rates and diazotrophic community composition between Pocillopora and Goniopora suggest that diazotrophy in the coral holobiont might not have a straightforward relationship with trophic position, unlike previously suggested [10]. Studies using a larger range of species are needed to determine how coral-associated diazotrophy varies with host physiology.

\section{DDN budgets}

In phosphate- and silicate-replete tropical waters, the water column diazotrophic community is typically comprised of diatomdiazotroph associations [29, 30]. While we found abundant diatom sequences in the seawater and in coral tissue, no ASVs from $16 \mathrm{~S}$ rRNA and nifH seawater samples were related to known diazotroph-associated diatoms [93], and overall, few sequences from Clusters I-III were present. During our study, the water column N:P ratio was $\approx 14.5$, which may explain the low diazotrophic abundance and diversity in the water column [34]. The water column N:P ratio may also drive low rates of mucusassociated diazotrophy, as mucus microbial communities are influenced by the seawater microbial community $[79,80]$. Based on budget estimates, neither water column $\mathrm{N}_{2}$ fixation nor transfer of DDN to the water column via released mucus were a significant source of new nitrogen production at the time of this study (Table S6).

Despite low rates of $\mathrm{N}_{2}$ fixation, we found that DDN might still be a relevant nitrogen source for the coral holobiont. The endolithic community accounts for only $1.4-15 \%$ of total holobiont respiration [84, 94, 95] and may have a lower growth rate than the coral tissue. By assuming the same growth rate (and nitrogen demand) for the endolithic community and coral tissue, we may have overestimated overall holobiont nitrogen demand, in which case DDN would have met more than $6 \%$ of daily growth demand. However, as little is known about endolithic growth rates in corals, and endoliths need to keep up with skeletal deposition, growth rates may in fact be similar to that of the tissue. Nevertheless, skeletal porewater is rich in dissolved organic nutrients $[96,97]$, and skeletal nitrogen regeneration by the total endolithic community has been estimated to satisfy $55-65 \%$ of daily holobiont $\mathrm{N}$ requirements in $M$. annularis [97]. These studies, together with the high rate of endolithic DDN assimilation and higher 16S RNA:DNA ratios of endolithic diazotrophs, suggest that endolith-derived DDN has the potential to be an important source of nitrogen for the coral holobiont.

\section{Diazotrophic community}

The nifH ASVs in our corals were predominately from Clusters I, III, and V. The majority of sequences were from Cluster V ( $89 \%$ of ASVs), which contains nifH homologs involved in chlorophyll biosynthesis that are not known to fix nitrogen (cf. [98, 99]). A similar result was also reported by Lesser et al. [8] using the same primers, which capture a large diversity of nifH sequences $[56,100]$, where $\sim 89 \%$ of ASVs were placed in Cluster V. The majority of our Cluster $V$ sequences were most closely related to chlorophyllide reductase subunit $\mathrm{L}$ from Ostreobium plastids and Alphaproteobacteria (Rhodobacterales, Rhizobiales), which were all highly abundant in the $16 \mathrm{~S}$ rRNA microbial community (Figs. S5 and S6). Given the prevalence of Cluster $\mathrm{V}$ nifH sequences across coral species, analyses of nifH diversity or gene copy number that do not differentiate between nifH clusters (e.g., $[10,24,101])$ could overestimate diazotrophic diversity and activity in coral. Moreover, taxa containing Cluster V chlorophyllide genes, such as Ostreobium, are known to bloom during coral bleaching events [86], which means that particular care must be exercised when analyzing nifH abundance in bleaching studies.

Comparison of the nifH and 16S rRNA DNA- and RNA-based communities revealed that despite differences in the microbial community between tissue and skeletal compartments, the nifH community within a given species was similar between the tissue and skeleton. However, 16S RNA:DNA ratios suggested differences in diazotrophic activity between compartments. In particular, nonheterocystous nitrogen-fixing Cyanobacteria were more abundant and had higher 16S RNA:DNA ratios in the skeleton than the tissue in Platygyra and Pocillopora, and were also part of the nifH-based community in all skeletal samples (Fig. 5). As non-heterocystous Cyanobacteria are commonly found in coral skeletons [102], they may be key members of the coral diazotrophic community. Moreover, as Cyanobacteria can bloom in response to heat stress [103], proliferation of endolithic Cyanobacteria during coral bleaching may explain the increased $\mathrm{N}_{2}$ fixation rates measured in multiple experiments [11, 24] (Fig. 7). Future studies should use Cyanobacteria-specific nifH probes to accurately quantify their activity, particularly during bleaching. Other potentially important members of the skeletal diazotrophic community included the sulfate-reducing bacteria Halodesulfovibrio (Desulfovibrionales), which have been previously isolated from coral endolithic communities [104] and were identified here as relatively active in Platygyra and Pocillopora; Chloroflexi, which had high 16S RNA: DNA in the skeleton of all species; Gammaproteobacteria (Alteromonadales), particularly in the skeleton of Pocillopora and Goniopora; and Pseudoxanthobacter (Rhizobiales), which were only identified as relatively active in the skeleton of Goniopora. In coral tissue, Rhodospirillales of the family Terasakiellaceae, which contains nitrogen fixers and may be associated with healthy coral tissue [105-108], had high 16S RNA:DNA ratios in the tissue of all species.

Within the RNA-based nifH diazotrophic community, the majority of Clusters I-III sequences were comprised of Gammaproteobacteria and Cyanobacteria, whereas Deltaproteobacteria, while present in the DNA-based community, were not abundant (Fig. S14). Across all species, most RNA-based nifH ASVs belonged to Cluster I, including Goniopora, which had a high abundance of Cluster III diazotrophs in the DNA-based community (Fig. 5). Photosynthetic activity by both Symbiodiniaceae and endolithic algae (e.g., Ostreobium) likely favor diazotrophs from Cluster I, which are either aerobic or facultatively anaerobic. In coral tissue, Symbiodiniaceae-derived photosynthates have been proposed as a source of carbon for coral-associated diazotrophs [12, 109]. Correspondingly, we propose that Ostreobium may provide a carbon source for endolithic diazotrophs. Although transfer of carbon from Symbiodiniaceae or Ostreobium to diazotrophs has yet to be directly documented, such a relationship may explain why some of the highest rates of DDN assimilation reported in the literature were measured in short, day-time experiments [14, 23]. While our incubations lasted $24 \mathrm{~h}$, our nifH community composition suggests that the majority of coral-associated diazotrophs are able to tolerate aerobic conditions. However, as incubations were retrieved around midday, our experimental timing may have 
biased the RNA-based nifH community toward Cluster I. While not abundant in the RNA-based community, multiple Cluster III nifH ASVs related to sulfate-reduction and sulfur-oxidation were abundant both in the skeleton and tissue (Fig. 5), and 16S RNA: DNA ratios indicated that multiple Deltaproteobacteria taxa were active in the tissue and skeleton. Together, these findings suggest that both compartments are capable of hosting anaerobic $\mathrm{N}_{2}$ fixation. Nevertheless, the coexistence of Clusters I and III, even if in the DNA-based community, highlights the heterogeneity of microbial niches in coral skeleton and tissue. Moreover, as the majority of Cyanobacteria were non-heterocystous, their ability to fix nitrogen might depend on temporal or spatial separation from oxygen production.

As a number of potentially diazotrophic Alphaproteobacteria were abundant in the $16 \mathrm{~S}$ rRNA community, notably Rhizobiales, it is surprising that these taxa were not equally abundant in the nifH Clusters I-III sequences. Rhizobiales contains many known diazotrophs that may associate with microalgae [110,111] and have been found in varying abundance in coral microbial communities [8, 11, 112]. While Rhizobiales have been proposed as possible diazotrophic coral symbionts [112], their role in coral $\mathrm{N}_{2}$ fixation is still debated, particularly as some species contain only Cluster $\mathrm{V}$ nifH homologs and do not appear to fix nitrogen $[8,111]$. We found that Rhizobiales had low relative activity in both the tissue and skeleton (16S RNA:DNA <1), and that the majority of Rhizobiales in the nifH community had Cluster $\mathrm{V}$ nifH homologs. Within the nifH Clusters I-III community, only Rhizobiales most closely related to Aurantimonadaceae, a family associated with coral white plague disease, displayed signs of activity (16S RNA:DNA =4.6, Fig. S16). Therefore, despite the abundance of Rhizobiales in our coral samples (especially in the skeleton), it is unlikely that this group was an important part of the diazotrophic community. In future work, more direct techniques, such as RNA stable isotope probing, should be used to validate the taxa-specific trends in relative diazotrophic activity observed here.

While DNA-based microbial community analysis has reshaped our understanding of corals, our knowledge of microbial activity within the coral holobiont is still extremely limited. RNA:DNA ratios are a well-established method for investigating relative microbial activity [39-42], although this method cannot be used as an absolute measure of activity. rRNA gene copy numbers can vary between species and as a function of metabolic state or cell size, and growth rates are not always simply correlated with rRNA concentrations (cf. [42]). To account for these limitations, ratios should be interpreted between related taxonomic groups [40, 42], and RNA-based community composition should be considered as a relative indicator of protein synthesis, rather than an absolute indicator [42]. Despite these considerations, RNA:DNA ratios can provide useful insight into the functionality of coral microbial communities and may be a particularly useful metric during periods of environmental stress.

\section{CONCLUSIONS}

Our results demonstrate that while seawater- and mucusassociated $\mathrm{N}_{2}$ fixation rates may be low during nutrient-replete conditions, diazotrophs in the coral tissue and skeleton still fix nitrogen on a scale that is relevant to the daily $\mathrm{N}$ growth demand of the coral. The majority of RNA-based nifH ASVs were from Cluster I (aerobes or facultative anaerobes), supporting the hypothesis that coral-associated diazotrophs tolerate hyperoxic conditions [8, 33]. Given rate discrepancies between incubations of variable length $[14,23]$, as well as the abundance of Cluster I, we hypothesize that diazotrophy may be linked to photosynthetically derived carbon sources in the tissue and skeleton [12, 109]. Studies at higher spatial and temporal resolution are needed to determine both the carbon source of coral-associated diazotrophs, and the diurnal dynamics of $\mathrm{N}_{2}$ fixation and photosynthesis within the holobiont. While Rhizobiales, a proposed mutualistic symbiont, were abundant in the coral microbial community, we found little evidence that they had the capacity for $\mathrm{N}_{2}$ fixation. Our results particularly highlight the importance of the endolithic community for coral-associated diazotrophy, and we suggest that the magnitude of endolithic diazotrophy may account for discrepancies between ${ }^{15} \mathrm{~N}_{2}$ - and ARA-based studies. The biogeochemical and physiological significance of the endolithic community is still largely uncharacterized and should be a focus for future research. Between coral species, we found no relationship between trophic position or symbiont clade and DDN assimilation. Instead, physiological differences between species, such as tissue biomass, mucus content, and skeletal density, likely structure the microbial community and create habitats more or less favorable for diazotrophy.

\section{REFERENCES}

1. Bell P. Eutrophication and coral reefs-some examples in the Great Barrier Reef lagoon. Water Res. 1992;26:553-68

2. Odum HT, Odum EP. Trophic structure and productivity of a windward coral reef community on Eniwetok Atoll. Ecol Monogr. 1955;25:291-320.

3. Ainsworth TD, Krause L, Bridge T, Torda G, Raina JB, Zakrzewski M, et al. The coral core microbiome identifies rare bacterial taxa as ubiquitous endosymbionts. ISME J. 2015;9:2261-74.

4. Ceh J, Kilburn MR, Cliff JB, Raina JB, van Keulen M, Bourne DG. Nutrient cycling in early coral life stages: Pocillopora damicornis larvae provide their algal symbiont (Symbiodinium) with nitrogen acquired from bacterial associates. Ecol Evol. 2013;3:2393-400.

5. Fine M, Loya Y. Endolithic algae: an alternative source of photoassimilates during coral bleaching. Proc R Soc B. 2002;269:1205-10.

6. Benavides $M$, Bednarz VN, Ferrier-Pagès $C$. Diazotrophs: overlooked key players within the coral symbiosis and tropical reef ecosystems? Front Mar Sci. 2017;4:2261-17.

7. Cardini U, Bednarz VN, van Hoytema N, Rovere A, Naumann MS, Al-Rshaidat $M M D$, et al. Budget of primary production and dinitrogen fixation in a highly seasonal Red Sea coral reef. Ecosystems. 2016;19:771-85.

8. Lesser MP, Morrow KM, Pankey SM, Noonan SHC. Diazotroph diversity and nitrogen fixation in the coral Stylophora pistillata from the Great Barrier Reef. ISME J. 2018;12:813-24.

9. Bednarz VN, van de Water JAJM, Rabouille S, Maguer JF, Grover R, Ferrier-Pagès C. Diazotrophic community and associated dinitrogen fixation within the temperate coral Oculina patagonica. Environ Microbiol. 2018;21:480-95.

10. Pogoreutz C, Rädecker N, Cárdenas A, Gärdes A, Wild C, Voolstra CR. Nitrogen fixation aligns with nifH abundance and expression in two coral trophic functional groups. Front Microbiol. 2017;8:1187.

11. Davey $M$, Holmes $G$, Johnstone R. High rates of nitrogen fixation (acetylene reduction) on coral skeletons following bleaching mortality. Coral Reefs. 2007;27:227-36.

12. Lesser MP, Falcón LI, Rodríguez-Román A, Enríquez S, Hoegh-Guldberg O, Iglesias-Prieto R. Nitrogen fixation by symbiotic cyanobacteria provides a source of nitrogen for the scleractinian coral Montastraea cavernosa. Mar Ecol Prog Ser. 2007;346:143-52.

13. Olson ND, Ainsworth TD, Gates RD, Takabayashi M. Diazotrophic bacteria associated with Hawaiian Montipora corals: diversity and abundance in correlation with symbiotic dinoflagellates. J Exp Mar Biol Ecol. 2009;371:140-6.

14. Benavides $M$, Houlbrèque $F$, Camps $M$, Lorrain A, Grosso O, Bonnet S. Diazotrophs: a non-negligible source of nitrogen for the tropical coral Stylophora pistillata. J Exp Biol. 2016;219:2608-12.

15. Cardini U, Bednarz V, Naumann MS, van Hoytema N, Rix L, Foster RA, et al. Functional significance of dinitrogen fixation in sustaining coral productivity under oligotrophic conditions. Proc R Soc B. 2015;282:20152257.

16. Grover R, Ferrier-Pagès $C$, Maguer JF, Ezzat L, Fine $M$. Nitrogen fixation in the mucus of Red Sea corals. J Exp Biol. 2014;217:3962-3.

17. Mohr W, Großkopf T, Wallace DWR, LaRoche J. Methodological underestimation of oceanic nitrogen fixation rates. PLoS ONE. 2010;5:e12583.

18. Montoya JP, Voss M, Kahler P, Capone DG. A simple, high-precision, highsensitivity tracer assay for N2 fixation. Appl Environ Microbiol. 1996;62:986-93.

19. Bednarz VN, Grover R, Maguer JF, Fine $M$, Ferrier-Pagès $C$. The assimilation of diazotroph-derived nitrogen by scleractinian corals depends on their betabolic status. MBio. 2017;8:e02058-16. 
20. Meunier V, Bonnet S, Pernice M, Benavides M, Lorrain A, Grosso O, et al. Bleaching forces coral's heterotrophy on diazotrophs and Synechococcus. ISME J. 2019;13:2882-6.

21. Cardini U, van Hoytema N, Bednarz VN, Rix L, Foster RA, Al-Rshaidat MMD, et al. Microbial dinitrogen fixation in coral holobionts exposed to thermal stress and bleaching. Environ Microbiol. 2016;18:2620-33.

22. Moisander PH, Beinart RA, Hewson I, White $A E$, Johnson KS, Carlson CA, et al. Unicellular cyanobacterial distributions broaden the oceanic N2 fixation domain. Science. 2010;327:1512-4.

23. Sangsawang $L$, Casareto BE, Ohba H, Vu HM, Meekaew A, Suzuki T, et al. $13 \mathrm{C}$ and $15 \mathrm{~N}$ assimilation and organic matter translocation by the endolithic community in the massive coral Porites lutea. R Soc Open Sci. 2017;4:171201.

24. Pogoreutz C, Rädecker N, Cárdenas A, Gärdes A, Voolstra CR, Wild C. Sugar enrichment provides evidence for a role of nitrogen fixation in coral bleaching. Glob Chang Biol. 2017;23:3838-48.

25. D'Angelo C, Wiedenmann J. Impacts of nutrient enrichment on coral reefs: new perspectives and implications for coastal management and reef survival. Curr Opin Environ Sustain. 2014;7:82-93.

26. Capone DG, O'Neil JM, Zehr J, Carpenter EJ. Basis for diel variation in nitrogenase activity in the marine planktonic Cyanobacterium Trichodesmium thiebautii. Appl Environ Microbiol. 1990;56:3532-6.

27. Mulholland MR, Ohki K, Capone DG. Nutrient controls on nitrogen uptake and metabolism by natural populations and cultures of Trichodesmium (Cyanobacteria). J Phycol. 2001;37:1001-9.

28. Mulholland MR, Bernhardt PW, Widner BN, Selden CR, Chappell PD, Clayton S, et al. High rates of N2 fixation in temperate, western North Atlantic coastal waters expand the realm of marine diazotrophy. Global Biogeochem Cycles. 2019;33:826-40.

29. Wen Z, Lin W, Shen R, Hong H, Kao SJ, Shi D. Nitrogen fixation in two coastal upwelling regions of the Taiwan Strait. Sci Rep. 2017;7:1-10.

30. Grosse J, Bombar D, Doan HN, Nguyen LN, Voss M. The Mekong River plume fuels nitrogen fixation and determines phytoplankton species distribution in the South China Sea during low and high discharge season. Limnol Oceanogr. 2010;55:1668-80

31. Mills MM, Turk-Kubo KA, Dijken GL, Henke BA, Harding K, Wilson ST, et al. Unusual marine cyanobacteria/haptophyte symbiosis relies on $\mathrm{N} 2$ fixation even in N-rich environments. ISME J. 2020;14:2395-406.

32. Henke BA, Turk-Kubo KA, Bonnet S, Zehr JP. Distributions and abundances of sublineages of the N2fixing cyanobacterium Candidatus Atelocyanobacterium thalassa (UCYN-A) in the New Caledonian coral lagoon. Front Microbiol. 2018;9:554.

33. El-Khaled YC, Roth F, Tilstra A, Rädecker N, Karcher DB, Kürten B, et al. In situ eutrophication stimulates dinitrogen fixation, denitrification, and productivity in Red Sea coral reefs. Mar Ecol Prog Ser. 2020;645:55-66.

34. Knapp AN. The sensitivity of marine N2 fixation to dissolved inorganic nitrogen. Front Microbiol. 2012;3:374.

35. Rädecker N, Pogoreutz C, Voolstra CR, Wiedenmann J, Wild C. Nitrogen cycling in corals: the key to understanding holobiont functioning? Trends Microbiol. 2015;23:1490-7.

36. Erler DV, Shepherd BO, Linsley BK, Nothdurft LD, Hua Q, Lough JM. Has nitrogen supply to coral reefs in the South Pacific Ocean changed over the past 50 thousand years? Paleoceanogr Paleoclimatol. 2019;34:567-79.

37. Pratte ZA, Richardson LL, Mills DK. Microbiota shifts in the surface mucopolysaccharide layer of corals transferred from natural to aquaria settings. J Invertebr Pathol. 2015;125:42-4.

38. Kooperman N, Ben-Dov E, Kramarsky-Winter E, Barak Z, Kushmaro A. Coral mucus-associated bacterial communities from natural and aquarium environments. FEMS Microbiol Lett. 2007;276:106-13.

39. Kirchman DL. Growth rates of microbes in the oceans. Annu Rev Mar Sci. 2016;8:285-309.

40. Hu SK, Campbell V, Connell P, Gellene AG, Liu Z, Terrado R, et al. Protistan diversity and activity inferred from RNA and DNA at a coastal ocean site in the eastern North Pacific. FEMS Microbiol Ecol. 2016;92:fiw050.

41. Campbell BJ, Kirchman DL. Bacterial diversity, community structure and potential growth rates along an estuarine salinity gradient. ISME J. 2013;7:210-20.

42. Blazewicz SJ, Barnard RL, Daly RA, Firestone MK. Evaluating rRNA as an indicator of microbial activity in environmental communities: limitations and uses. ISME J. 2013;7:2061-8.

43. Massana R, Gobet A, Audic S, Bass D, Bittner L, Boutte C, et al. Marine protist diversity in European coastal waters and sediments as revealed by highthroughput sequencing. Environ Microbiol. 2015;17:4035-49.

44. Bauman AG, Hoey AS, Dunshea G, Feary DA, Low J, Todd PA. Macroalgal browsing on a heavily degraded, urbanized equatorial reef system. Sci Rep. 2017;7:1-8.

45. Januchowski-Hartley FA, Bauman AG, Morgan KM, Seah JCL, Huang D, Todd PA. Accreting coral reefs in a highly urbanized environment. Coral Reefs. 2020;39:717-31.
46. Klawonn I, Lavik G, Böning P, Marchant HK, Dekaezemacker J, Mohr W, et al. Simple approach for the preparation of 15-15N2-enriched water for nitrogen fixation assessments: evaluation, application and recommendations. Front Microbiol. 2015;6:769.

47. Pupier CA, Bednarz VN, Grover R, Fine M, Maguer JF, Ferrier-Pagès C. Divergent capacity of scleractinian and soft corals to assimilate and transfer diazotrophically derived nitrogen to the reef environment. Front Microbiol. 2019;10:1860.

48. Bombar D, Paerl RW, Anderson R, Riemann L. Filtration via conventional glass fiber filters in 15N2 tracer assays fails to capture all nitrogen-fixing prokaryotes. Front Mar Sci. 2018;5:e00929-11.

49. R Core Team. R: a language and environment for statistical computing. 2019. https://www.R-project.org/.

50. Hansen HP, Koroleff F. Determination of nutrients. In: Grasshoff K, Kremling K, Ehrhardt M, editors. Methods of seawater analysis. Weinheim, Germany: Wiley; 1999. p. 159-228.

51. Morgan KM, Moynihan MA, Sanwlani N, Switzer AD. Light limitation and depthvariable sedimentation drives vertical reef compression on turbid coral reefs. Front Mar Sci. 2020;7:571256.

52. Comeau AM, Li WKW, Tremblay JÉ, Carmack EC, Lovejoy C. Arctic ocean microbial community structure before and after the 2007 record sea ice minimum. PLoS ONE. 2011;6:e27492.

53. Kwong WK, del Campo J, Mathur V, Vermeij MJA, Keeling PJ. A widespread coralinfecting apicomplexan with chlorophyll biosynthesis genes. Nature. 2019;568:103-7.

54. Comeau AM, Douglas GM, Langille MGI. Microbiome helper: a custom and streamlined workflow for microbiome research. mSystems. 2017;2:e00127-16.

55. Weiler BA. Bacterial Communities in tissues and surficial mucus of the coldwater coral Paragorgia arborea. Front Mar Sci. 2018;5:378.

56. Gaby JC, Buckley DH. A comprehensive evaluation of PCR primers to amplify the nifH gene of nitrogenase. PLoS ONE. 2012;7:e42149.

57. Bower SM, Carnegie RB, Goh B, Jones SRM, Lowe GJ, Mak MWS. Preferential PCR amplification of parasitic protistan small subunit rDNA from metazoan tissues. J Eukaryot Microbiol. 2004;51:325-32.

58. Piredda R, Tomasino MP, D'Erchia AM, Manzari C, Pesole G, Montresor M, et al. Diversity and temporal patterns of planktonic protist assemblages at a Mediterranean long term ecological research site. FEMS Microbiol Ecol. 2016;93:fiw200.

59. Callahan BJ, McMurdie PJ, Rosen MJ, Han AW, Johnson AJA, Holmes SP. DADA2: high-resolution sample inference from Illumina amplicon data. Nat Methods. 2016;13:581-3.

60. Callahan BJ, Sankaran K, Fukuyama JA, McMurdie PJ, Holmes SP. Bioconductor workflow for microbiome data analysis: from raw reads to community analyses. F1000Research. 2016:5:1492.

61. Quast C, Pruesse E, Yilmaz P, Gerken J, Schweer T, Yarza P, et al. The SILVA ribosomal RNA gene database project: improved data processing and webbased tools. Nucleic Acids Res. 2012;41:D590-6.

62. McLaren MR. Silva SSU taxonomic training data formatted for DADA2 (Silva version 138) [Data set]. Zenodo; 2020. https://doi.org/10.5281/ zenodo.3731176.

63. Guillou L, Bachar D, Audic S, Bass D, Berney C, Bittner L, et al. The protist ribosomal reference database (PR2): a catalog of unicellular eukaryote small sub-unit rRNA sequences with curated taxonomy. Nucleic Acids Res. 2013;41:D597-604.

64. Heller P, Tripp JH, Turk-Kubo K, Zehr JP. ARBitrator: a software pipeline for ondemand retrieval of auto-curated nifH sequences from GenBank. Bioinformatics. 2014;30:2883-90.

65. Moynihan MA. moyn413/nifHdada2: nifH dada2 reference database, v1.1.0. Zenodo; 2020. https://doi.org/10.5281/zenodo.3964214.

66. McMurdie PJ, Holmes S. phyloseq: an R package for reproducible interactive analysis and graphics of microbiome census data. PLoS ONE. 2013;8:1-11.

67. Love $\mathrm{Ml}$, Huber $\mathrm{W}$, Anders $\mathrm{S}$. Moderated estimation of fold change and dispersion for RNA-seq data with DESeq2. Genome Biol. 2014;15:1-21.

68. Letunic I, Bork P. Interactive Tree Of Life (iTOL): an online tool for phylogenetic tree display and annotation. Bioinformatics. 2007;23:127-8.

69. Bell PRF, Elmetri I, Lapointe BE. Evidence of large-scale chronic eutrophication in the Great Barrier Reef: quantification of chlorophyll a thresholds for sustaining coral reef communities. Ambio. 2013;43:361-76.

70. Conti-Jerpe IE, Thompson PD, Wong CWM, Oliveira NL, Duprey NN, Moynihan $\mathrm{MA}$, et al. Trophic strategy and bleaching resistance in reef-building corals. Sci Adv. 2020;6:eaaz5443.

71. Ferrier-Pagès $C$, Witting J, Tambutté $E$, Sebens KP. Effect of natural zooplankton feeding on the tissue and skeletal growth of the scleractinian coral Stylophora pistillata. Coral Reefs. 2003;22:229-40.

72. Ferrier-Pagès $C$, Hoogenboom $M$, Houlbrèque $F$. The role of plankton in coral trophodynamics. In: Dubinsky Z, Stambler N, editors. Coral reefs: an ecosystem in transition. Dordrecht, The Netherlands: Springer; 2011. p. 215-29. 
73. Pernice M, Raina JB, Rädecker N, Cárdenas A, Pogoreutz C, Voolstra CR. Down to the bone: the role of overlooked endolithic microbiomes in reef coral health. ISME J. 2020;14:325-34.

74. Huggett MJ, Apprill A. Coral microbiome database: integration of sequences reveals high diversity and relatedness of coral-associated microbes. Environ Microbiol Rep. 2019;11:372-85.

75. Méheust R, Castelle CJ, Carnevali PBM, Farag IF, He C, Chen LX, et al. Groundwater Elusimicrobia are metabolically diverse compared to gut microbiome Elusimicrobia and some have a novel nitrogenase paralog. ISME J. 2020;14:2907-22.

76. Nomata J, Mizoguchi T, Tamiaki H, Fujita Y. A second nitrogenase-like enzyme for bacteriochlorophyll biosynthesis: reconstitution of chlorophyllide a reductase with purified X-protein (BchX) and YZ-protein (BchY-BchZ) from Rhodobacter capsulatus. J Biol Chem. 2006;281:15021-8.

77. Suzuki JY, Bauer CE. Light-independent chlorophyll biosynthesis: involvement of the chloroplast gene chlL (frxC). Plant Cell. 1992;4:929-40.

78. Bednarz VN, Naumann MS, Cardini U, van Hoytema N, Rix L, Al-Rshaidat MMD, et al. Contrasting seasonal responses in dinitrogen fixation between shallow and deep-water colonies of the model coral Stylophora pistillata in the northern Red Sea. PLoS ONE. 2018;13:e0199022.

79. Weber L, González Díaz P, Armenteros M, Apprill A. The coral ecosphere: a unique coral reef habitat that fosters coral-microbial interactions. Limnol Oceanogr. 2019;64:2373-88.

80. Bourne DG, Munn CB. Diversity of bacteria associated with the coral Pocillopora damicornis from the Great Barrier Reef. Environ Microbiol. 2005;7:1162-74.

81. Pernice M, Meibom A, Van Den Heuvel A, Kopp C, Domart-Coulon I, HoeghGuldberg $O$, et al. A single-cell view of ammonium assimilation in coral-dinoflagellate symbiosis. ISME J. 2012;6:1314-24.

82. Kopp C, Pernice M, Domart-Coulon I, Djediat C, Spangenberg JE, Alexander D, et al. Highly dynamic cellular-level response of symbiotic coral to a sudden increase in environmental nitrogen. MBio. 2013;4:e00052-13.

83. Magnusson $\mathrm{SH}$, Fine $\mathrm{M}, \mathrm{Kühl} \mathrm{M}$. Light microclimate of endolithic phototrophs in the scleractinian corals Montipora monasteriata and Porites cylindrica. Mar Ecol Prog Ser. 2007;332:119-28.

84. Schlichter D, Zscharnack B, Krisch H. Transfer of photoassimilates from endolithic algae to coral tissue. Naturwissenschaften. 1995;82:561-4.

85. Kemp DW, Colella MA, Bartlett LA, Ruzicka RR, Porter JW, Fitt WK. Life after cold death: reef coral and coral reef responses to the 2010 cold water anomaly in the Florida Keys. Ecosphere. 2016;7:e01373.

86. Fine M, Roff G, Ainsworth TD, Hoegh-Guldberg O. Phototrophic microendoliths bloom during coral "white syndrome". Coral Reefs. 2006;25:577-81.

87. Fine $M$, Oren $U$, Loya $Y$. Bleaching effect on regeneration and resource translocation in the coral Oculina patagonica. Mar Ecol Prog Ser. 2002;234:119-25.

88. Littman RA, Willis BL, Pfeffer C, Bourne DG. Diversities of coral-associated bacteria differ with location, but not species, for three acroporid corals on the Great Barrier Reef. FEMS Microbiol Ecol. 2009:68:152-63.

89. Dunphy CM, Gouhier TC, Chu ND, Vollmer SV. Structure and stability of the coral microbiome in space and time. Sci Rep. 2019;9:1-13.

90. Le Campion-Alsumard T, Golubic S, Hutchings P. Microbial endoliths in skeletons of live and dead corals: Porites lobata (Moorea, French Polynesia). Mar Ecol Prog Ser. 1955;117:149-57.

91. Yang SH, Tandon K, Lu CY, Wada N, Shih CJ, Hsiao SSY, et al. Metagenomic, phylogenetic, and functional characterization of predominant endolithic green sulfur bacteria in the coral Isopora palifera. Microbiome. 2019;7:1-13.

92. Yost DM, Wang LH, Fan TY, Chen CS, Lee RW, Sogin E, et al. Diversity in skeletal architecture influences biological heterogeneity and Symbiodinium habitat in corals. Zoology. 2013;116:262-9.

93. Fiore $\mathrm{CL}$, Jarett JK, Olson ND, Lesser MP. Nitrogen fixation and nitrogen transformations in marine symbioses. Trends Microbiol. 2010;18:455-63.

94. Jacques TG, Pilson MEQ. Experimental ecology of the temperate scleractinian coral Astrangia danae I. Partition of respiration, photosynthesis and calcification between host and symbionts. Mar Biol. 1983;60:167-78.

95. Shashar N, Stambler N. Endolithic algae within corals-life in an extreme environment. J Exp Mar Biol Ecol. 1992;163:277-86.

96. Risk MJ, Muller HR. Porewater in coral heads: evidence for nutrient regeneration. Limnol Oceanogr. 1983:28:1004-8.

97. Ferrer LM, Szmant AM. Nutrient regeneration by the endolithic community in coral skeletons. In: Proceedings of the 6th International Coral Reef Symposium. 2. Townsville, Australia: AIMS; 1988. p. 1-4.

98. Raymond J, Siefert JL, Staples CR, Blankenship RE. The natural history of nitrogen fixation. Mol Biol Evol. 2004;21:541-54.

99. Gaby JC, Buckley DH. A global census of nitrogenase diversity. Environ Microbiol. 2011;13:1790-9.

100. Gaby JC, Rishishwar L, Valderrama-Aguirre LC, Green SJ, Valderrama-Aguirre A, Jordan IK, et al. Diazotroph community characterization via a high-throughput nifH amplicon sequencing and analysis pipeline. Appl Environ Microbiol. 2018;84: e01512-17.

101. Liang J, Yu K, Wang Y, Huang X, Huang W, Qin Z, et al. Diazotroph diversity associated with scleractinian corals and its relationships with environmental variables in the South China Sea. Front Physiol. 2020;11:615.

102. Marcelino VR, Morrow KM, van Oppen MJH, Bourne DG, Verbruggen H. Diversity and stability of coral endolithic microbial communities at a naturally high pCO2 reef. Molecular Ecology. 2017;26:5344-57.

103. Leggat WP, Camp EF, Suggett DJ, Heron SF, Fordyce AJ, Gardner S, et al. Rapid coral decay is associated with marine heatwave mortality events on reefs. Curr Biol. 2019;29:2723-30.

104. Chen YH, Yang SH, Tandon K, Lu CY, Chen HJ, Shih CJ, et al. A genomic view of coral-associated Prosthecochloris and a companion sulfate-reducing bacterium. bioRxiv. 2019. https://doi.org/10.1101/2019.12.20.883736.

105. Weiler BA, Verhoeven JTP, Dufour SC. Bacterial communities in tissues and surficial mucus of the cold-water coral Paragorgia arborea. Front Mar Sci. 2018;5:378.

106. Tiedje J. Ecology of denitrification and dissimilatory nitrate reduction to ammonium. In: Zehnder J, editor. Environmental microbiology of anaerobes. NY: John Wiley and Sons; 1988. p. 179-244.

107. Becker CC, Brandt M, Miller C, Apprill A. Stony coral tissue loss disease biomarker bacteria identified in corals and overlying waters using a rapid field-based sequencing approach. bioRxiv. 2021. https://doi.org/10.1101/2021.02.17.431614.

108. Parker KE, Ward JO, Eggleston EM, Fedorov E, Parkinson JE, Dahlgren CP, et al Characterization of a thermally tolerant Orbicella faveolata reef in Abaco, The Bahamas. Coral Reefs. 2020;39:675-85.

109. Tilstra A, El-Khaled YC, Roth F, Rädecker N, Pogoreutz C, Voolstra CR, et al. Denitrification aligns with N2 fixation in Red Sea corals. Sci Rep. 2019;9:1-9.

110. Kim BH, Ramanan R, Cho DH, Oh HM, Kim HS. Role of Rhizobium, a plant growth promoting bacterium, in enhancing algal biomass through mutualistic interaction. Biomass Bioenerg. 2014;69:95-105.

111. Wu Z, Yang $X$, Lin S, Lee WH, Lam PKS. Isolation and characterization of a Rhizobium bacterium associated with the toxic dinoflagellate Gambierdiscus balechii. bioRxiv. 2019. https://doi.org/10.1101/789107.

112. Lema KA, Willis BL, Bourne DG. Corals form characteristic associations with symbiotic nitrogenfixing bacteria. Appl Environ Microbiol. 2012;78:3136-44.

113. Anders S, Huber W. Differential expression analysis for sequence count data. Genome Biol. 2010;11:R106.

114. Shashar N, Cohen Y, Loya $Y$, Sar N. Nitrogen fixation (acetylene reduction) in stony corals: evidence for coral-bacteria interactions. Mar Ecol Prog Ser. 1994;111:259-64.

115. Bednarz VN, Cardini U, van Hoytema N, Al-Rshaidat M, Wild C. Seasonal variation in dinitrogen fixation and oxygen fluxes associated with two dominant zooxanthellate soft corals from the northern Red Sea. Mar Ecol Prog Ser. 2015:519:141-52.

\section{ACKNOWLEDGEMENTS}

Many thanks to Ashleen Su Ying Tan, Rob S. Nichols, Zhou Yongli, Nikita Kaushal, Kristy Yi Wen Chang, Leon Sun Wai Loong, Adam Emami, and Cyrus Emami for field assistance, and to Mr. Francis Yeo, Sapari, Suprapto, and Mel of Dolphin Explorer. Thank you to Daniel Vaulot for critical feedback on the manuscript and bioinformatic advice, and to Regine Hui Yi Tiong, Denise Rui Ying Ong, Chen Shuang, Christaline George, and Wenshu Yap for laboratory assistance and guidance. Authors greatly appreciate the technical support of Kit Sum Leung of The University of Hong Kong Stable Isotope Laboratory; the GeT-PlaGe Genotoul Sequencing Platform, Toulouse, France; and the University of California Davis Stable Isotope Facility. We would also like to thank three anonymous reviewers whose thorough and constructive comments improved this manuscript. This research was supported by the Earth Observatory of Singapore, the National Research Foundation of Singapore, the Singapore Ministry of Education and the Research Centres of Excellence Initiative, and the Marine Science R\&D Programme (MSRDP-P11). Corals were collected under permit number NP/RP17-044a from the Singapore National Parks Board. This work comprises EOS contribution number 375 .

\section{AUTHOR CONTRIBUTIONS}

MAM, PM, NFG, and FML conceived the study. MAM, KMM, PYYK, NFG, and PM conducted field experiments. MAM, PM, ALS, PYYK, and KMM were involved with field and/or laboratory protocol development. MAM, PYYK, and DMB processed samples. MAM analyzed data and drafted the manuscript with guidance from ALS, PM, and NFG. All authors were involved in data interpretation and critically revised the manuscript. 


\section{COMPETING INTERESTS}

The authors declare no competing interests.

\section{ADDITIONAL INFORMATION}

Supplementary information The online version contains supplementary material available at https://doi.org/10.1038/s41396-021-01054-1.

Correspondence and requests for materials should be addressed to M.A.M.

Reprints and permission information is available at http://www.nature.com/reprints

Publisher's note Springer Nature remains neutral with regard to jurisdictional claims in published maps and institutional affiliations.
Open Access This article is licensed under a Creative Commons Attribution 4.0 International License, which permits use, sharing, adaptation, distribution and reproduction in any medium or format, as long as you give appropriate credit to the original author(s) and the source, provide a link to the Creative Commons license, and indicate if changes were made. The images or other third party material in this article are included in the article's Creative Commons license, unless indicated otherwise in a credit line to the material. If material is not included in the article's Creative Commons license and your intended use is not permitted by statutory regulation or exceeds the permitted use, you will need to obtain permission directly from the copyright holder. To view a copy of this license, visit http://creativecommons. org/licenses/by/4.0/.

(c) The Author(s) 2021 